\title{
LIMITES DO PODER DIRETIVO DO GESTOR NAS RELAÇÕES DE TRABALHO: UMA ANÁLISE DE CASOS DE ASSÉDIO MORAL E PROFISSIONAL
}

\author{
LIMITS OF THE MANAGERIAL POWER OF THE MANAGER IN THE LABOR \\ RELATIONS: AN ANALYSIS OF CASES OF MORAL AND PROFESSIONAL \\ MOBBING
}

\author{
LÍMITES DEL PODER DIRECTIVO DEL GESTOR EN LAS RELACIONES DE \\ TRABAJO: UN ANÁLISIS DE CASOS DE ACOSO MORAL Y PROFESSIONAL
}

\begin{abstract}
YUMARA LÚCIA VASCONCELOS
https://orcid.org/0000-0003-2280-7692 / http://lattes.cnpq.br/5958622062616956 /yumaravasconcelos@gmail.com Universidade Federal Rural de Pernambuco - UFRPE

Recife, PE, Brasil.
\end{abstract}

RAFAELA MARIA José BERTINO https://orcid.org/0000-0002-8246-8293 / http://lattes.cnpq.br/2757203405794580 / bertino.rafaela@gmail.com Universidade Federal Rural de Pernambuco - UFRPE Recife, PE, Brasil.

\begin{abstract}
RESUMO
Essa investigação objetiva, em nível geral, identificar uma possível relação entre as modalidades de assédio (moral e profissional) e as agressões mais frequentes albergadas em cada uma delas. Secundariamente, visa classificar os casos de assédio analisados a partir de suas características distintivas, com vistas a mapear, organizar e categorizar as agressões mais recorrentes. O levantamento, de natureza qualitativa, com finalidade exploratório-descritiva, toma por base situações jurídicas de assédio levadas aos tribunais (alegações e depoimentos). Os resultados revelam indícios inequívocos de correlação entre as modalidades de assédio e as agressões mais recorrentes (padrão de configuração). Igualmente, estabelece diferenças objetivas entre o assédio moral e aquele profissional.
\end{abstract}

Palavras-chave: assédio moral; assédio profissional; dignidade humana.

\begin{abstract}
This objective investigation, on a general level, to identify a possible relationship between the types of harassment (moral and professional) and the most frequent aggressions housed in each one of them. Secondarily, it aims to classify the cases of harassment analyzed from its distinctive characteristics, in order to map, organize and categorize the most recurrent aggressions. The survey, of a qualitative nature, with an exploratory-descriptive purpose, is based on legal situations of harassment brought before the courts (allegations and testimony). The results reveal unequivocal evidence of a correlation between harassment patterns and the most recurrent aggressions (pattern of configuration). Likewise, it establishes objective differences between bullying and that professional.
\end{abstract}

Key words: harassment; professional harassment; human dignity. 


\section{RESUMEN}

Esta investigación objetiva, a nivel general, identificar una posible relación entre las modalidades de acoso (moral y profesional) y las agresiones más frecuentes albergadas en cada una de ellas. En segundo lugar, pretende clasificar los casos de acoso analizados a partir de sus características distintivas, con miras a mapear, organizar y categorizar las agresiones más recurrentes. El levantamiento, de naturaleza cualitativa, con propósito exploratorio-descriptivo, toma por base situaciones jurídicas de acoso llevadas a los tribunales (alegaciones y testimonios). Los resultados revelan indicios inequívocos de correlación entre las modalidades de acoso y las agresiones más recurrentes (patrón de configuración). Igualmente, establece diferencias objetivas entre el acoso moral y aquel profesional.

Palabras clave: acoso moral; acoso profesional; dignidad humana.

\section{SUMÁRIO}

INTRODUÇÃO; 10 ASSÉDIO MORAL COMO VIOLAÇÃO A DIGNIDADE HUMANA; 2 METODOLOGIA; 3 ANÁLISE E DISCUSSÃO DE RESULTADOS; 3.1 Faces e características do fenômeno; 3.2 Repercussão da inatividade gerencial; 3.3 Tipologia do assédio; 3.4 Consequências do assédio moral; 3.5 Poder e práticas gerenciais; CONCLUSÃO; REFERÊNCIAS.

\section{INTRODUÇÃO}

0 assédio moral é definido como violência psicológica interpessoal, presente em relações autoritárias e assimétricas. ${ }^{1}$ De caráter continuado, a conduta expõe o indivíduo a situações humilhantes e constrangedoras, as quais, naturalmente, produzem sofrimento íntimo e desconforto social em níveis crescentes. ${ }^{2}$

Para caracterização da conduta, o meio utilizado (documentos, postagens nas redes sociais, gestos) afigura-se irrelevante à sua configuração. Embora inexista consenso na literatura acerca da precisa caracterização do fenômeno, é possível identificar pontos de convergência para sua definição: lesividade (teor ofensivo); pessoalidade, conduta ativa ou omissiva; frequência (série de atos empreendidos em pequenos intervalos), regularidade ou progressão de intensidade, intencionalidade, planejamento, organização e o potencial de encadear danos à pessoa (físicos e psíquicos). ${ }^{3}$ Se a caracterização não é unânime, o entendimento acerca da gravidade dos efeitos para a vida do trabalhador é pacífico na doutrina. ${ }^{4}$

\footnotetext{
${ }^{1}$ NEGRI, Sergio. Mobbing: nove storie di lavoro e ingiustizia quotidiana. Itália: Libreria Universitaria, 2011. ${ }^{2}$ ALKIMIN, Maria Aparecida. Assédio moral na relação de trabalho. Curitiba: Juruá Editora, 2013. ${ }^{3}$ GUIMARÃES, Liliana Andolpho Magalhães; RIMOLI, Adriana Odalia. "Mobbing" (assédio psicológico) no trabalho: uma síndrome psicossocial multidimensional. Psicologia: Teoria e Pesquisa, Brasília, v. 22, n. 2, p. 183-191, ago. 2006. Disponível em:

https: / / www.scielo.br/scielo.php?pid=S010237722006000200008\&script=sci_abstract\&tlng=pt Acesso em 20 maio 2017.

${ }^{4}$ LORENTE, Marisa Bosqued. Mobbing: como prevenir y superar el acoso psicológico. Barcelona: Paidós Contextos, 2005.
} 
ISSN 1981-3694

(DOI): $10.5902 / 1981369437184$

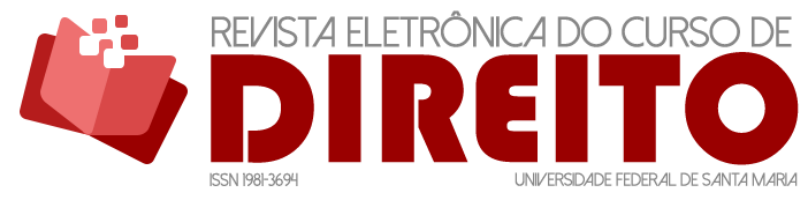

LIMITES DO PODER DIRETIVO DO GESTOR NAS RELAÇÕES DE TRABALHO: UMA ANÁLISE DE CASOS DE ASSEEDIO MORAL E PROFISSIONAL

YUMARA LÚCIA VASCONCELOS RAFAELA MARIA JOSÉ BERTINO

$\mathrm{Na}$ rotina dos tribunais, o conceito comporta situações de assédio movidas por objetivos pessoais (do ofensor), em que a pessoalidade é um elemento fulcral da caracterização, e aqueles profissionais (razões corporativas), com motivação completamente impessoal. ${ }^{5}$ Estudos jurídicos já reconhecem a classificação do assédio a partir do critério da natureza dos motivos, embora em um âmbito prático essa diferença não traga uma repercussão significativa nas decisões. As variantes do fenômeno são tratadas uniformemente.

A despeito da ressonância indiferente, a classificação afigura-se pertinente. 0 assédio profissional é movido por objetivos corporativos e visa incrementos na rentabilidade do negócio. Por força dessa característica é denominado de objetivista, organizacional ou institucional. A literatura apresenta, inclusive, denominações alternativas, o que corrobora sua natureza (assédio empresarial, assédio patronal e assédio corporativo). De fato, o assédio profissional sujeita o trabalhador às políticas espúrias e agressivas de desempenho das organizações. Alguns pesquisadores utilizam as expressões assédio moral empresarial e assédio moral institucional, embora inadequadas ao sentido defendido. O assédio moral, por sua vez, é denominado de subjetivista, dada a sua pessoalidade. ${ }^{6}$

Entende-se que a clareza conceitual é essencial ao adequado enquadramento da conduta, para o empreendimento de medidas gerenciais eficazes e de sanções cominatórias eficazes à mitigação do fenômeno. ${ }^{7}$ Ante o exposto, elege-se como questão problematizante: existe relação entre os tipos de assédio e as agressões empreendidas? Complementarmente: existe um padrão de conduta para cada tipo? De modo que, realizada a identificação de possível relação entre as modalidades de assédio (moral e profissional) e as agressões mais frequentes albergadas em cada uma delas, visa-se classificar os casos de assédio analisados a partir de suas características distintivas, com vistas a mapear, organizar e categorizar as agressões mais recorrentes.

A investigação realizada assenta-se na constatação de que os padecimentos emocionais estão cada vez mais explícitos, reclamando intervenção gerencial proativa. Nessa toada, importa ressaltar que

\footnotetext{
${ }^{5}$ VASCONCELOS, Yumara Lúcia. Assédio moral nos ambientes corporativos. Cadernos EBAPE-BR, Rio de Janeiro, v. 13, n. 4, p. 821-851, 2015. Disponível em: https://www.scielo.br/pdf/cebape/v13n4/16793951-cebape-13-04-00821.pdf. Acesso em 10 maio 2017.

${ }^{6}$ SANTOS, Cibele Carneiro da Cunha Macedo. Assédio moral e a responsabilidade civil empresarial. In: GARCIA, Gustavo Filipe Barbosa; ALVARENGA, Rúbia Zanotelli. de. Direito do trabalho e Direito empresarial. São Paulo: LTr, 2015.

${ }^{7}$ HIRIGOYEN, Marie-France. Todo lo que hay que saber sobre el acoso moral en el trabajo. Barcelona: Paidós Contextos, p. 21-44, 2014.
} 
Quando se examina o local do trabalho, sua importância na existência individual e social contemporânea, deve-se compreender sua significação ética. Dois aspectos essenciais devem ser mencionados a esse respeito. Em primeiro lugar, em qualquer hipótese e circunstância, o homem deve afirmar e consolidar, em qualquer época e cultura, na universalidade do tempo, sua condição de ser humano. Por meio do trabalho, em segundo lugar, o homem também deve realizar-se e revelar-se em sua identidade social e emancipação política. ${ }^{8}$

Os abusos praticados no ambiente laboral têm provocado reflexões acerca dos limites de atuação do indivíduo na organização, especialmente gestores. "O ser humano, ao trabalhar, busca não apenas, e tão somente, a sua sobrevivência. Procura, também, realizar-se como pessoa, alcançar consideração e respeito a sua dignidade." ${ }^{10}$ Esses excessos afrontam princípios gerenciais e aqueles jurídicos, garantidores dos direitos humanos, especialmente o princípio da boa fé objetiva, que alcança os diferentes tipos de contrato, inclusive o de trabalho. De fato, “Tal princípio tem por base a lealdade, a probidade, a ética nas relações jurídicas e busca sempre observar as considerações do outro (alter)."11

0 volume de casos de assédio coloca em relevo a necessidade de se investigar interdisciplinarmente o mundo do trabalho, com vistas a oferecer respostas (preventivas e de intervenção) eficazes a tais fenômenos.

\section{ASSÉDIO MORAL COMO VIOLAÇÃO A DIGNIDADE HUMANA}

Constitui diretiva constitucional a preservação de direitos sociais. A livre iniciativa, alicerce do projeto desenvolvimentista neoliberal, se esbarra nessa tutela, embora não se sobreponha à proteção desses direitos. ${ }^{12}$

\footnotetext{
${ }^{8}$ GUNTER, Luiz Eduardo. 0 assédio moral no ambiente do trabalho: dano moral e/ou dano existencial? Incidências da reforma trabalhista. In: GUNTER, Luiz Eduardo. ALVARENGA, R. Z. de. SCHIO, Adriana Cavalcante de Souza (Org). Reforma trabalhista: impacto e aplicação da lei n. 13.467/2017. São Paulo: Ltr, 2018, p. 39.

${ }^{9}$ FREITAS, Maria Éster de. Existe uma saúde moral nas organizações?. Organizações \& Sociedade, v. 12, n. 32, p. 13-27, 2005. Disponível em: https://www.scielo.br/scielo.php?script=sci_arttext\&pid=S198492302005000100001 Acesso em 10 maio 2017.

${ }^{10}$ GUNTER, Luiz Eduardo. 0 assédio moral no ambiente do trabalho: dano moral e/ou dano existencial? Incidências da reforma trabalhista. In: GUNTER, Luiz Eduardo. ALVARENGA, R. Z. de; SCHIO, Adriana Cavalcante de Souza (Org). Reforma trabalhista: impacto e aplicação da lei n. 13.467/2017. São Paulo: Ltr, 2018, p. 39.

${ }^{11}$ SANTOS, Cibele Carneiro da Cunha Macedo. Assédio moral e a responsabilidade civil empresarial. In: GARCIA, Gustavo Filipe Barbosa; ALVARENGA, Rúbia Zanotelli. de. Direito do trabalho e Direito empresarial. São Paulo: LTr, 2015, p. 116.

${ }^{12}$ FREITAS, Maria Éster de. Existe uma saúde moral nas organizações?. Organizações \& Sociedade, v. 12, n. 32, p. 13-27, 2005. Disponível em: https://www.scielo.br/scielo.php?script=sci_arttext\&pid=S1984$\underline{92302005000100001}$ Acesso em 10 maio 2017.
} 
ISSN 1981-3694

(DOI): $10.5902 / 1981369437184$

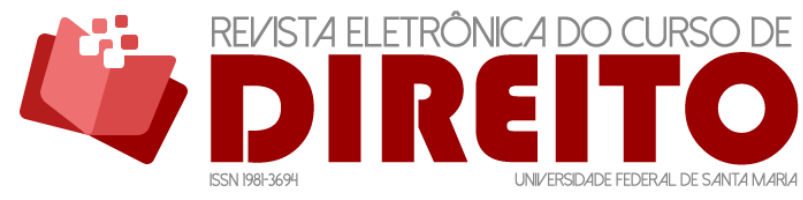

LIMITES DO PODER DIRETIVO DO GESTOR NAS RELAÇÕES DE TRABALHO: UMA ANÁLISE DE CASOS DE ASSEEDIO MORAL E PROFISSIONAL

YUMARA LÚCIA VASCONCELOS RAFAELA MARIA JOSÉ BERTINO

O conceito de subordinação jurídica é fundamental à compreensão e identificação de abusos no exercício da gestão. A submissão do trabalhador é restrita ao objeto contratado, que é a prestação do serviço. Assim, não alcança a pessoa e os direitos da personalidade, os quais comportam elementos como integridade psicológica, honra, intimidade, autodeterminação, identidade, privacidade e imagem, patrimônios intangíveis, inatos, intransmissíveis, indisponíveis, impenhoráveis e inalienáveis. ${ }^{13}$

A subordinação, na relação contratual em questão, não destitui a dignidade das partes, portanto, seus direitos da personalidade. 0 poder diretivo possui um escopo juridicamente definido, limitando-se à organização e controle do trabalho, não atingindo a autodeterminação da pessoa. A submissão não se confunde com a sujeição, pois o poder que sujeita nega a existência do outro, tolhindo sua expressão, capacidade de resistência e até de trabalho. ${ }^{14}$

A prerrogativa de dirigir a atividade econômica constitui-se como direito potestativo, aquele sobre o qual não recai qualquer questionamento, desde que não exorbite em seu exercício, extrapolando o aludido escopo. Embora o comando diretivo seja incontroverso, essa submissão se dá no âmbito jurídico-financeiro, sendo essa a natureza que define os contornos de sua aplicação. ${ }^{15} \mathrm{O}$ respaldo legal do poder de mando não desresponsabiliza o empregador e seus prepostos de manter um ambiente de trabalho saudável, adequado à realização das atividades contratadas e facilitador do desenvolvimento das pessoas e suas competências. É inequívoca a dimensão social do trabalho, alavanca propulsora do exercício de outros direitos. ${ }^{16}$

O direito a resistência e de contraponto ao poder diretivo se inserem no escopo dos direitos humanos porque decorrem da autodeterminação do indivíduo. Com efeito, o poder diretivo deve ser exercido com ponderação, não sujeitando o trabalhador em absoluto. Significa afirmar que a subordinação não implica submissão em matérias ou situações que ultrapassem a seara da relação jurídica e seu objeto, que é o serviço prestado. A faculdade de mando autoriza o empregador e seus prepostos designados (gestores) a dirigi-lo no âmbito das atividades contratadas. Qualquer prática contrária coisifica a pessoa, destituindo-lhe a autodeterminação, tal como ocorre no trabalho escravo. Portanto, na relação de trabalho há de se respeitar a

\footnotetext{
${ }^{13}$ BELTRÃO, Silvio Romero. Direitos da personalidade. São Paulo: Atlas, 2014.

${ }^{14}$ CASTRO, Cláudio Roberto Carneiro de. 0 que você precisa saber sobre assédio moral nas relações de emprego: doutrina, jurisprudência e casos concretos atuais. São Paulo: LTR, 2014.

${ }^{15}$ OLMOS, Cristina Paranhos. Direitos da personalidade nas relações de trabalho: limitação, relativização e disponibilidade. São Paulo: LTr, 2017.

${ }^{16}$ MIKOS, Nadia Regina de Carvalho; VILLATORE, Marco Antônio César. Poderes do empregador: do uso ao abuso e suas consequências socioeconômicas. In: GARCIA, Gustavo Filipe Barbosa. ALVARENGA, Rúbia Zanotelli de. Direito do trabalho e direito empresarial: sob o enfoque dos direitos fundamentais. São Paulo : LTr, 2015.
} 
identidade e liberdade do indivíduo. ${ }^{17}$ A gerência do processo de prestação do serviço não alcança a personalidade do agente executor. Não obstante, se reconheça a autonomia desse poder, os princípios da boa fé e da dignidade humana refreiam seu exercício, impondo ao agente contratante deveres colaterais. ${ }^{18}$

Assentada nos pilares da liberdade e autonomia, a dignidade humana é preservada no exercício pleno destes direitos. ${ }^{19}$ Trata-se de um conceito cujo teor é existencial. 0 próprio conceito de 'mínimo existencial' guarda relação direta com as condições necessárias à existência humana que, embora não apresente conteúdo específico para essas condições, comporta requisitos à manutenção de um ambiente de trabalho emocionalmente saudável. ${ }^{20}$

De fato, a dignidade humana é direito básico e deve ser respeitada. ${ }^{21} \mathrm{~A}$ despeito da dignidade, Barroso e Barcellos esclarecem: “A dignidade relaciona-se tanto com a liberdade e valores do espírito como com as condições materiais de subsistência."22 Conquanto se trate de um conceito intuitivo e lógico, o princípio jurídico da dignidade humana se impõe com notável força normativa e moral, refletindo-se nas práticas e relacionamentos sociais, atingindo obviamente as relações de trabalho. ${ }^{23}$

Indisponível e irrenunciável, ao irradiar-se nesse âmbito, a diretiva reclama a atenção de gestores relativamente aos limites de acesso e abordagem da administração ao indivíduo na organização. Exige, igualmente, ponderações acerca da demarcação invisível da identidade do

\footnotetext{
${ }^{17}$ GUNTHER, Luiz Eduardo. 0 direito da personalidade e suas repercussões na atividade empresarial. In: Gunther, Luíz Eduardo (Coord.). Tutela dos direitos da personalidade na atividade empresarial. Curitiba: Juruá, 2008.

${ }^{18}$ OLMOS, Cristina Paranhos. Direitos da personalidade nas relações de trabalho: limitação, relativização e disponibilidade. São Paulo: LTr, 2017.

${ }^{19}$ GARCÍA, Eusebio Fernández. Dignidad humana y ciudanía cosmopolita. Madrid: Editorial Dykinson, 2001.

${ }^{20}$ MIKOS, Nadia Regina de Carvalho; VILLATORE, Marco Antônio César. Poderes do empregador: do uso ao abuso e suas consequências socioeconômicas. In: GARCIA, Gustavo Filipe Barbosa. ALVARENGA, Rúbia Zanotelli de. Direito do trabalho e direito empresarial: sob o enfoque dos direitos fundamentais. São Paulo : LTr, 2015.

${ }^{21}$ GARCÍA, Eusebio Fernández. Dignidad humana y ciudanía cosmopolita. Madrid: Editorial Dykinson, 2001.

${ }^{22}$ BARROSO, Luis Roberto; DE BARCELLOS, Ana Paula. O começo da história. A nova interpretação constitucional e o papel dos princípios no direito brasileiro. Revista de direito administrativo, v. 232, p. 141-176, abr./jun., 2003. p. 171. Disponível em: http://bibliotecadigital.fgv.br/ojs/index.php/rda/article/view/45690 Acesso em 10 maio 2017

${ }^{23}$ GUERRA, Sidney; EMERIQUE, Lílian Márcia Balmant. O princípio da dignidade da pessoa humana e o mínimo existencial. Revista da Faculdade de Direito de Campos, v. 7, n. 9, p. 379-398, 2006. Disponível em: http://fdc.br/Arquivos/Mestrado/Revistas/Revista09/Artigos/Sidney.pdf Acesso em 20 maio 2017
} 
ISSN 1981-3694

(DOI): $10.5902 / 1981369437184$

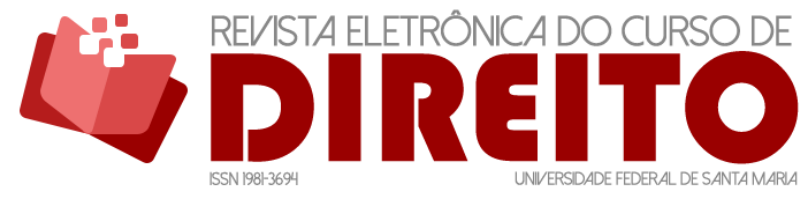

LIMITES DO PODER DIRETIVO DO GESTOR NAS RELAÇÕES DE TRABALHO: UMA ANÁLISE DE CASOS DE ASSÉDIO MORAL E PROFISSIONAL

YUMARA LÚCIA VASCONCELOS RAFAELA MARIA JOSÉ BERTINO

trabalhador (esfera de intimidade e privacidade).$^{24} \mathrm{O}$ princípio da dignidade da pessoa humana afigura-se inclusivo, apresentando-se como cláusula abrangente, harmonizando os valores próprios de um Estado Democrático de Direito. ${ }^{25}$ Assim, como afirma Santos, “Ao exercer o poder diretivo, o empregador deve ter por limite, além daqueles traçados pelo objeto do contrato de trabalho, a condição humana do trabalhador."26

O conceito de dignidade humana tem relação direta com o direito justo, e no plano gerencial, com aqueles relacionados à ética e civilidade nas relações profissionais. ${ }^{27} 0$ assédio moral ou profissional viola os limites da dignidade da pessoa humana e, portanto, da legalidade. ${ }^{28}$ Representa, igualmente, um ultraje àqueles signos distintivos que formam e individualizam a pessoa, refletindo sua identidade afetiva, étnico-racial, política, social, ideológica e cultural. ${ }^{29} 0$ ambiente de trabalho, por essa lente, se impõe como locus de desenvolvimento e construção dessas identidades, onde qualquer afronta aos direitos personalíssimos obstaculiza esse processo.

Essa constatação eleva o comportamento humano a um status de relevo nas práticas gerenciais, sob pena de impactar negativamente a imagem corporativa perante a sociedade, face à promoção de danos existenciais à saúde do trabalhador. 0 prejuízo à imagem corporativa deve ser mencionado porque notícias de assédio moral ou qualquer outra forma extravagante de exigência não permanecem restritas à organização.

Os excessos ou abuso de poder ocorrem não somente no decurso da fase contratual, alcançando a fase pré e pós-contratual, independente da vinculação jurídica ínsita à relação de trabalho. Configura-se como prática abusiva na fase pré-contratual:

- $\quad$ tratativas frustradas por má fé do empregador;

\footnotetext{
24PAVELSKI, Ana Paula. Relação de emprego e direitos de personalidade: por um emprego digno. In: Gunther, Luíz Eduardo (Coord.). Tutela dos direitos da personalidade na atividade empresarial. Curitiba: Juruá, 2008.

${ }^{25}$ SILVA, José Afonso da. A dignidade da pessoa humana com valor supremo da democracia. Revista de direito administrativo, v. 212, p. 89-94, 1998. Disponível em: http://bibliotecadigital.fgv.br/ojs/index.php/rda/article/view/47169/45637. Acesso em 10 maio 2017.

${ }^{26}$ SANTOS, Cibele Carneiro da Cunha Macedo. Assédio moral e a responsabilidade civil empresarial. In: GARCIA, Gustavo Filipe Barbosa; ALVARENGA, Rúbia Zanotelli. de. Direito do trabalho e Direito empresarial. São Paulo: LTr, 2015, p. 117.

${ }^{27}$ SILVA, José Afonso da. A dignidade da pessoa humana com valor supremo da democracia. Revista de direito administrativo, v. 212, p. 89-94, 1998. Disponível em:

http://bibliotecadigital.fgv.br/ojs/index.php/rda/article/view/47169/45637. Acesso em 10 maio 2017. ${ }^{28}$ PITHAN, Lívia Haygert. A dignidade humana como fundamento jurídico das 'ordens de não ressurreição'. Porto Alegre: EDIPUCS, 2004.

${ }^{29}$ ROJO, José Vicente; CERVERA, Ana María Mobbing o acoso laboral. Madrid: Editorial Tébar, p 21-60 2005.
} 
ISSN 1981-3694

(DOI): $10.5902 / 1981369437184$

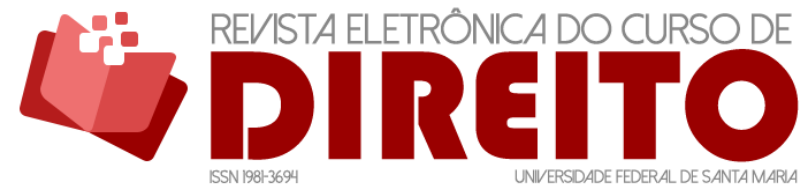

LIMITES DO PODER DIRETIVO DO GESTOR NAS RELAÇÕES DE TRABALHO: UMA ANÁLISE DE CASOS DE ASSEEDIO MORAL E PROFISSIONAL

YUMARA LÚCIA VASCONCELOS RAFAELA MARIA JOSÉ BERTINO

- dinâmicas de grupo vexatórias, que desvalorizam as identidades, incitando a discriminação;

- $\quad$ exclusão do candidato (a) habilitado (a) em razão de sua orientação sexual, afiliação ideológica ou partidária, aparência, e no caso da mulher, estado gravídico;

- $\quad$ submissão do (a) candidato (a) a testes de polígrafo, dentre outras iniciativas desnecessárias à verificação de sua qualificação. exigências subjetivas, em geral, têm dado azo a reclamatórias trabalhistas.

0 abuso pós-contratual, em geral, se verifica quando o empregador inclui e divulga o nome do empregado em 'listas negras', causando dano direto ao trabalhador. Neste sentido, os autores Mikos e Villatore apresentam situações que podem ser interpretadas como abuso no exercício do poder diretivo: “(...) sistema de monitoramento eletrônico inadequado, escuta de conversas telefônicas, rastreamento de mensagens eletrônicas, imposição de horários para utilização de banheiros, por exemplo."30

No decurso do contrato, esses abusos, em geral são mais bem caracterizados, especialmente nos casos de assédio moral, apesar do direito potestativo de mando decorrente do exercício do poder diretivo. Entretanto, a linha que divisa o assédio moral daquele meramente profissional é bastante tênue, baseando-se essencialmente nos motivos que movem a violência. Um exemplo emblemático dessa afirmação é a revista de empregados, que a priori seria um procedimento albergado pelo direito do empregador de exercer o controle patrimonial ou do serviço prestado. Ocorre que quando essa abordagem se dá de modo vexatório, está configurado o abuso. É pacificado o entendimento de que a revista não implica o direito de despir o empregado (a) ou de prover qualquer contato físico, o que violaria a intimidade do revistado (a), tutelada pelo Direito Civil.

A prática do poder diretivo, especialmente aquele de controle, está intrinsecamente relacionada ao direito de propriedade, que também é uma diretiva constitucional. Todavia, não significa que os direitos da personalidade não devam ser também respeitados, uma vez que também consta no mesmo Diploma legal. As substâncias dessas diretivas não são excludentes, mas sim, paralelas. A inserção no mundo do trabalho não implica a perda desses direitos. Assim, o exercício do controle nesse universo reclama cuidados em razão da necessidade de se respeitar

\footnotetext{
${ }^{30}$ MIKOS, Nadia Regina de Carvalho; VILLATORE, Marco Antônio César. Poderes do empregador: do uso ao abuso e suas consequências socioeconômicas. In: GARCIA, Gustavo Filipe Barbosa. ALVARENGA, Rúbia Zanotelli de. Direito do trabalho e direito empresarial: sob o enfoque dos direitos fundamentais. São Paulo : LTr, 2015, p. 84
} 
ISSN 1981-3694

(DOI): $10.5902 / 1981369437184$

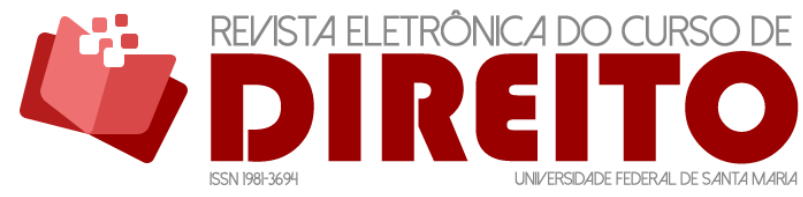

LIMITES DO PODER DIRETIVO DO GESTOR NAS RELAÇÕES DE TRABALHO: UMA ANÁLISE DE CASOS DE ASSEEDIO MORAL E PROFISSIONAL

YUMARA LÚCIA VASCONCELOS RAFAELA MARIA JOSÉ BERTINO

a privacidade do indivíduo. Controles invasivos constituem abuso, razão pela qual dão azo a grande parte das demandas judiciais.

Os direitos da personalidade alcançam a esfera íntima do indivíduo, o que justifica sua condição de inerente ao titular e núcleo mínimo que compõe a dignidade humana. Constituem, portanto, natureza extrapatrimonial e objeto intangível. São inatos, inseparáveis da pessoa e essenciais ao usufruto de sua dignidade, razão pela qual são imprescritíveis, guardando relação direta com valores éticos e morais vigentes. Em razão de sua natureza, não podem ser renunciados, sub-rogados, ou mesmo, alienados. Significa afirmar que o nexo sujeito-direito é orgânico. ${ }^{31}$

O substrato que preenche o conceito “dignidade" é inespecífico, inclusivo, plástico e abrangente, mas sensível nos casos de violação. O conhecimento, consentimento e anuência dos mecanismos de controle não são suficientes para garantir sua legitimidade, tendo em vistas as citadas restrições legais e humanísticas. ${ }^{32}$

A preocupação com o 'humano' nas relações de trabalho se ergue não somente como requisito de urbanidade, mas como diretriz de baliza moralmente valorativa. Embora o Direito Civil seja a especialidade que trata dos interesses da 'pessoa' (de particulares, âmbito privado), somente com o advento da Constituição de 1988 se destinou atenção aos direitos cuja substância ou objeto tem natureza não patrimonial.

0 reconhecimento dos direitos inerentes à pessoa adveio do constitucionalismo moderno, que os salvaguardou, plasmando no diploma jurídico seu caráter universal e transcendente, encarnando valores mais humanísticos (dignidade, liberdade e igualdade). Essas diretivas se irradiam a todo o ordenamento, alcançando as relações no mundo do trabalho e, por conseguinte, a administração das organizações.

0 volume de processos judiciais relacionados à violência no ambiente de trabalho tem delegado aos tribunais a responsabilidade de efetivar esses direitos. Ocorre que muitos vícios comportamentais são arraigados de tal modo que processos culturais reguladores não se mostram eficazes para disciplinar ou conformar, reclamando um processo cultural transformador e emancipatório, o que envolveria um despertamento social alicerçado na convicção.

\footnotetext{
${ }^{31}$ OLMOS, Cristina Paranhos. Direitos da personalidade nas relações de trabalho: limitação, relativização e disponibilidade. São Paulo: LTr, 2017.

32GUERRA, Sidney; EMERIQUE, Lílian Márcia Balmant. O princípio da dignidade da pessoa humana e o mínimo existencial. Revista da Faculdade de Direito de Campos, v. 7, n. 9, p. 379-398, 2006. Disponível em: http://fdc.br/Arquivos/Mestrado/Revistas/Revista09/Artigos/Sidney.pdf. Acesso em 20 maio 2017.
} 
O poder diretivo ou de gestão, legitimado institucionalmente funda-se no conceito de subordinação jurídica e não naquele de sujeição absoluta do trabalhador (parte hipossuficiente da relação de trabalho) aos interesses do (a) contratante. Considerando o assédio moral como infrator do princípio da igualdade, uma vez que patrocina a discriminação motivada por ascendência, patriarcalismo, religião, convicções político-ideológicas, nível de instrução, gênero, raça, condição social ou identidade afetivosexual. Afinal, o preceito magno da igualdade não nega a diversidade, ao contrário, reconhece-a e a naturaliza, uma vez que pressupõe relações isonômicas, condição essencial ao exercício da dignidade humana. 0 conceito amoldase ao objeto qualificador (raça, gênero ou qualquer outro sinal de identidade) e circunstâncias, as quais não excluem aquelas produzidas no ambiente de trabalho. As regras regimentais e normas de paridade se concretizam a partir desses contornos abstratos. Um dos princípios estruturantes do ordenamento de notado significado é o pluralismo político. Talvez, dentre os demais, seja o que melhor exernalize a essência e significado de um estado democrático de direito, dimensão que deu causa à Carta Magna de 1988. De fato,

A sociedade, que dá embasamento a essa ordem jurídica, não é uma sociedade monista, antes, apresenta as características de uma sociedade plural onde convivem em permanente ebulição, classes e grupos sociais, econômicos, financeiros, culturais e ideológicos de tons variados e gradações cambiantes. ${ }^{33}$

O princípio, em seu teor, reconhece a importância do conflito produtivo na sociedade e, por conseguinte, da diversidade e contraposições de interesses. 0 pluralismo político é nuclear no pensamento democrático. As sociedades democráticas são inclusivas, compreendendo pessoas diversas quanto a origem, classe social, riqueza, dentre outros parâmetros. ${ }^{34}$ Nessa construção, tem como consequência direta, o respeito a diferença e o empreendimento de ações que visem a manutenção da urbanidade nas relações, em situações onde se revelar tensões ou atritos.

Os princípios humanísticos circunscrevem o perímetro que oferece limites à atuação de gestores nos relacionamentos cotidianos no ambiente de trabalho. Mais que vetores

\footnotetext{
${ }^{33}$ LOPES, Maurício Antonio Ribeiro. Princípios políticos do Direito Penal. São Paulo: Revista dos tribunais, 1999, p. 257.

${ }^{34}$ DELGADO, Mauricio Goldinho. Relação de emprego e relações de trabalho: a retomada do expansionismo do Direito do trabalho. In: SENA, Adriana Goulart de; DELGADO, Gabriela Neves; NUNES, Raquel Portugal. Dignidade humana e inclusão social: caminhos para a efetividade do Direito do Trabalho no Brasil. São Paulo: LTr, 2010, p. 17 -33.
} 
ISSN 1981-3694

(DOI): $10.5902 / 1981369437184$

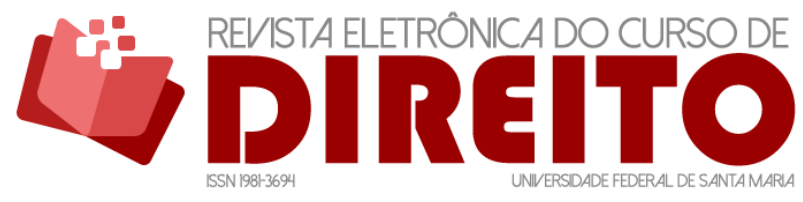

LIMITES DO PODER DIRETIVO DO GESTOR NAS RELAÇÕES DE TRABALHO: UMA ANÁLISE DE CASOS DE ASSEEDIO MORAL E PROFISSIONAL

YUMARA LÚCIA VASCONCELOS RAFAELA MARIA JOSÉ BERTINO

constitucionais, esses mandamentos basilares são indícios de civilidade. ${ }^{35}$ Decorre desse entendimento que o exercício do poder de comando pela administração exige, por força legal, o respeito à pessoa e suas singularidades, oportunizando a igualdade nos âmbitos político, civil e moral, sem retirar-lhes a autodeterminação e estima por si mesmo, traduzida em sua capacidade de escolha ou de decisão. Assim, qualquer conduta que incentive a discriminação viola de forma cediça essa diretiva natural. A prática de assédio moral se erige de modo fulcral em relações de desigualdade. ${ }^{36}$

0 usufruto dos direitos de mando do empregador e sua representação (gestores) compreende tão somente a organização, regulamentação, liderança, fiscalização, controle e disciplina, pois a subordinação não tem caráter pessoal, e sim, contratual. Nesse sentido, situações de assédio representam notórias violações contratuais, cuja repercussão perpassa as paredes institucionais.

\section{METODOLOGIA}

Essa investigação define-se como qualitativa, exploratório-descritiva e interdisciplinar, em razão da natureza dos dados explorados e objetivos de pesquisa propostos. ${ }^{37}$ Essencialmente documental, trata-se de uma pesquisa de levantamento.

A classificação da pesquisa como interdisciplinar teve como repercussão o aporte de diferentes acepções teóricas e metodológicas, como será descrito na sequência. Essa decisão encontrou amplo respaldo em protocolos tradicionais de pesquisa empírica, afigurando-se como tendência no Direito. ${ }^{38}$ É dessa maneira que as áreas de conhecimento dialogam atualmente, na tentativa de interpretar fenômenos com maior acuidade. ${ }^{39}$

A interdisciplinaridade se revela na integração de saberes e métodos de investigação com vistas a ensejar análises desfronteirizadas do fenômeno estudado. Temas multifacetados como o

\footnotetext{
${ }^{35}$ CAMARGO, Jota. Princípio da igualdade: efetividade dos direitos, liberdades e garantias das minorias e dos excluídos. In: DONIZETTI, Elpídio; GARBIN, Rosana Broglio; OLIVEIRA, Thiago de Diversos enfoques do princípio da igualdade. Belo Horizonte: Editora Fórum, 2014, p. 167-233.

${ }^{36} \mathrm{CUNICO}$, Miriam Machado. Saindo do silêncio: o assédio moral quase destruiu minha vida. Curitiba: Concep, 2014.

${ }^{37}$ FOWLER JÚNIOR, Floyd. Pesquisa de levantamento. Campinas, SP: Penso, 2011.

${ }^{38} \mathrm{ABIB}$, José Antônio Damásio. Epistemologia, transdisciplinaridade e método. Psicologia: teoria e pesquisa, v. 12, n. 3, p. 219-229, 1996.

${ }^{39}$ RAYNAUT, Claude. Dicotomia entre ser humano e natureza: paradigma fundador do pensamento científico. In: PHILIPPI Jr, Arlindo; FERNANCES, Valdir. Práticas da interdisciplinaridade no ensino e pesquisa. Barueri, SP: Manole, 2015.
} 
ISSN 1981-3694

(DOI): $10.5902 / 1981369437184$

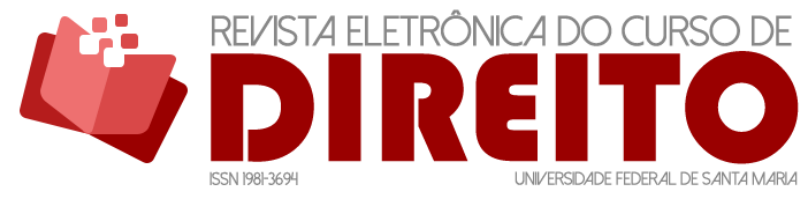

LIMITES DO PODER DIRETIVO DO GESTOR NAS RELAÇÕES DE TRABALHO: UMA ANÁLISE DE CASOS DE ASSEEDIO MORAL E PROFISSIONAL

YUMARA LÚCIA VASCONCELOS RAFAELA MARIA JOSÉ BERTINO

assédio moral reclamam um maior alcance de visão, o que é coerente, pois, nem o próprio recorte disciplinar é endógeno e estático. Articular os conhecimentos sem compartimentá-lo, ou promover blocagens, produz interpretações mais completas. ${ }^{40}$

Optou-se como método de procedimento o estudo de casos, analisando-se 20 (vinte) alegações de assédio moral levadas a juízo, oriundas de diferentes Tribunais (TRTs), sem qualquer delimitação temporal ou espacial, consideradas irrelevantes para a proposta deste estudo, pois, não se vislumbrou como ação de pesquisa a confrontação de posições e entendimentos. Definiu-se, entretanto, critérios para composição das unidades-caso, a saber: o enquadramento na definição da violência e a densidade narrativa.

Nesse intento, elegeu-se como objeto de exploração as narrativas de reclamantes, proponentes das ações judiciais motivadas por abusos nas relações de trabalho. Incorporou-se ao corpus empiricus dessa investigação, igualmente, o material discursivo produzido pelas falas dos depoentes transcritas nos acórdãos.

0 estudo de caso corresponde ao método de pesquisa apropriado quando se almeja explorar singularidades e a densidade do fenômeno investigado em seu campo de ocorrência. ${ }^{41}$ Desta forma, a base de dados foi composta tão somente por decisões prolatadas por tribunais superiores colegiados (de segunda instância). Não se analisou as decisões monocráticas em razão da dificuldade de acesso aos processos.

0 número de casos tomou por base os três critérios apresentados por Charmaz: ${ }^{42} 1$ - o teor e densidade dos casos; 2- a saturação teórica; 3- a suficiência e complexidade para atingimento dos objetivos propostos. De fato, não se objetivou a obtenção de um panorama representativo da violência no mundo do trabalho (estudo extensivo). 0 traço característico das investigações qualitativas é a opção pelo aprofundamento do detalhe, das particularidades do objeto, que pode ser atingido apenas por meio de estudos intensivos.

“Ao contrário, a pesquisa qualitativa segue o caminho da redução da extensão do domínio observado, a focalização sobre poucos casos, dos quais se propõe a individuar e representar os mínimos detalhes." 43

\footnotetext{
${ }^{40}$ EINARSEN, Ståle. The nature, causes and consequences of bullying at work: the Norwegian experience. Perspectives Interdisciplinaires Sur le Travail et la Santé, v. 7, n. 3, 2005.

${ }^{41}$ MERRIAM, Sharan B. Qualitative Research and Case Study Applications in Education. Revised and Expanded from Case Study Research in Education. Jossey-Bass Publishers, 350 Sansome St, San Francisco, CA 94104, 1998.

${ }^{42}$ CHARMAZ, Kathy. A construção da teoria fundamentada: guia prático para análise qualitativa. Porto Alegre: Bookman Editora, 2009.

${ }^{43}$ CARDANO, Mario. Manual de pesquisa qualitativa: a contribuição da teoria da argumentação. Petrópolis: Vozes, 2017, p. 35.
} 
O critério de saturação teórica, aplicável ao método de estudo de casos, relaciona-se à pertinência dos dados coletados ante as categorias de análise definidas em projeto. Essa pesquisa, portanto, está alicerçada apenas no levantamento e análise documental.

A escolha metodológica procedimental deveu-se às características dos estudos de caso nas investigações qualitativas e do paradigma que orientou os trabalhos, essencialmente interpretativista. 0 estudo de caso é a modalidade de pesquisa cujo objeto empírico é a unidade qualitativa - fenomenológica, denominada de unidade-caso. Sem a pretensão de apresentar generalizações ou descrições representativas optou-se, nessa investigação, pela espécie multicasos. Os estudos de natureza qualitativa colocam em relevo as perspectivas dos sujeitos da pesquisa envolvidos no fenômeno (narrativas, linguagem, sentimentos, pontos de vistas, ideologias, interpretações e experiências), o que é coerente com o design da investigação proposto. ${ }^{44}$ De fato,

[...] a maioria reconhece que a realidade relevante no que diz respeito a experiência humana é aquela que ocorre na experiência subjetiva, no contexto social e no tempo histórico. Assim, os pesquisadores qualitativos geralmente estão mais preocupados em descobrir o conhecimento sobre como as pessoas pensam, sentem e as circunstâncias em que se encontram do que em fazer julgamentos se esses pensamentos e sentimentos são válidos. ${ }^{45}$

Ao privilegiar o sujeito e os significados atribuídos, nas pesquisas qualitativas importa muito mais esclarecer impressões, posições e entendimentos do que meramente descrevê-los. ${ }^{46}$ As descrições, todavia, são componentes fundamentais da análise de conteúdo consequente. ${ }^{47}$ Trata-se de uma perspectiva fundamental a compreensão do fenômeno investigado e significados subjacentes. ${ }^{48}$ As investigações qualitativas protagonizam o sujeito da pesquisa, deslocando a atenção usualmente atribuída às estatísticas generalizantes, que margeiam a essência dos

\footnotetext{
${ }^{44}$ THORNE, Sally. Data analysis in qualitative research. Evidence based nursing, v. 3, n. 3, p. 68-70, 2000. Disponível em: https://ebn.bmj.com/content/ebnurs/3/3/68.full.pdf Acesso em 10 maio 2017.

${ }^{45}$ THORNE, Sally. Data analysis in qualitative research. Evidence based nursing, v. 3, n. 3, p. 68-70, 2000. Disponível em: https://ebn.bmj.com/content/ebnurs/3/3/68. full.pdf Acesso em 10 maio 2017. P. 68.

${ }^{46}$ SRIVASTAVA, Aashish; THOMSON, Stanley Bruce. Framework analysis: a qualitative methodology for applied policy research, JOAAG-Journal of Administration \& Governance. V. 4, n 2, p. 72-79, 2009.

${ }^{47}$ MINAYO, Maria Cecília de Souza. Análise qualitativa: teoria, passos e fidedignidade. Revista Ciência \& Saúde Coletiva, v. 17, n. 3, p. 621-626, 2012. Disponível em:https: / $/$ www.scielo.br/scielo.php?pid=\$141381232012000300007\&script=sci_abstract\&tlng=pt. Acesso em: 20 maio 2017.

${ }^{48}$ GUERRA, Isabel Carvalho. Pesquisa qualitativa e análise de conteúdo: sentidos e formas de uso. Rio de Janeiro: Lucerna, 2006.
} 
ISSN 1981-3694

(DOI): $10.5902 / 1981369437184$

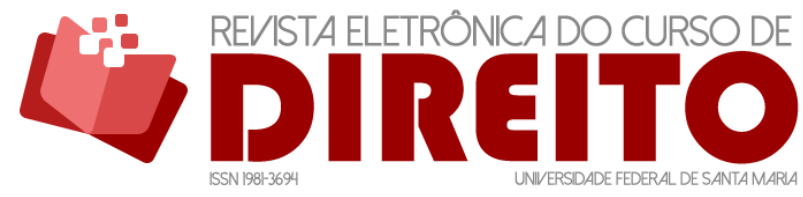

LIMITES DO PODER DIRETIVO DO GESTOR NAS RELAÇÕES DE TRABALHO: UMA ANÁLISE DE CASOS DE ASSEEDIO MORAL E PROFISSIONAL

YUMARA LÚCIA VASCONCELOS RAFAELA MARIA JOSÉ BERTINO

problemas sociais, invisibilizando os dados não representativos. Essa constatação foi a principal justificativa à conformação do protocolo metodológico-empírico com essa identidade. ${ }^{49}$

Com efeito, as investigações qualitativas exploram o campo (casos concretos) sob uma perspectiva menos estruturada, rígida e predita (diretiva pós-crítica), respeitando o decurso natural dos fatos sociais que comportam e as demandas que thes são próprias, sem priorizar a representatividade dos dados gerados. $^{50}$ Essa cautela de intervenção singulariza essas investigações, mesmo tratando-se de protocolos clássicos. ${ }^{51}$ A priori, o estudo de caso não é uma metodologia receptiva ao ideário pós-crítico, mas a plasticidade adotada na condução dos trabalhos deu base a essa identificação. A liberdade com que o pesquisador estabelece o percurso da investigação define esse enquadramento.

De fato, as metodologias pós-críticas são essencialmente voltadas ao fenômeno, realidade social e seu status quo. Nesse intento, exploram ideias, discursos e práticas sociais, adaptando o processo de pesquisa (etapas e recursos) às demandas emergentes de campo, considerando a dimensão contextual do conhecimento. Entende-se que a desconstrução do caráter normativo dos métodos não produz qualquer desconforto ou estranhamento ao pesquisador, apresentando tão somente caminhos possíveis e mais adequados à realidade investigada. Por essa lógica de pensamento, aplicar métodos rigidamente estruturados pode torná-lo estéril ante a complexidade ínsita ao campo.

0 conceito de direitos da personalidade é analisado casuisticamente à luz das narrativas de assédio em razão de sua ampla inclusividade, sendo a análise de conteúdo, método de análise de dados utilizado nesse estudo, ferramenta para a investigação das narrativas do sujeito (reclamante, suposta vítima de assédio, e demais atores sociais já mencionados), ação que encaminha à realização de inferências acerca dos conteúdos (expressão textual) e sentidos dos argumentos aduzidos; igualmente, de seu contexto social.

A estratégia não operou, portanto, o texto de per se sem contemplar o contexto da análise e de produção das unidades temáticas. Em razão dessas peculiaridades metodológicas, optou-se pela análise por categorias temáticas. ${ }^{52}$ Embora o método seja frequentemente associado à frequência de palavras, expressões, símbolos e modalizações nos textos, a análise de

\footnotetext{
${ }^{49}$ DENZIN, Norman Kent; LINCOLN, Yvonna Sessions. Handbook of qualitative research. Sage publications, inc., 1994.

${ }^{50}$ ACKERMAN, Sebastián Erneston; COM, Sérgio Luis. Metodología de la investigación. Buenos Aires, AR: Ediciones del Aula Taller, 2013.

${ }^{51}$ THORNE, Sally. Data analysis in qualitative research. Evidence based nursing, v. 3, n. 3, p. 68-70, 2000. Disponível em: https://ebn.bmj.com/content/ebnurs/3/3/68.full.pdf Acesso em 10 de maio de 2017.

52 BARDIN, Laurence. Análise de conteúdo. Lisboa: edições 70, 1977.
} 
ISSN 1981-3694

(DOI): $10.5902 / 1981369437184$

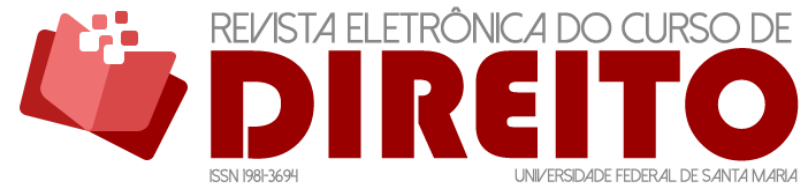

LIMITES DO PODER DIRETIVO DO GESTOR NAS RELAÇÕES DE TRABALHO: UMA ANÁLISE DE CASOS DE ASSÉDIO MORAL E PROFISSIONAL

YUMARA LÚCIA VASCONCELOS RAFAELA MARIA JOSÉ BERTINO

conteúdo enfatiza os significados subjacentes às entrelinhas, especialmente a compreensão crítica obtida a partir das inferências, potencial ratificado por diversos autores. ${ }^{53}$

0 percurso dessa investigação respeitou as seguintes etapas, a saber: 1- leitura exploratória ou inspecional dos acórdãos, visando verificar o enquadramento do caso ao escopo da proposta e à definição das categorias temáticas; 2- leitura significativa (sistemática) e codificação, com vistas a confirmação das unidades categóricas e análise em profundidade, seguindo o rito da análise de conteúdo; 3- Organização dos resultados e interpretação. Ressaltese que essa trajetória foi definida ao longo do processo de pesquisa. No que concerne, especificamente, à análise de conteúdo, o processo compreendeu a decomposição do texto em unidades de significação (léxicas ou temáticas). No caso em tela, a unidade textual foi essencialmente temática. A investigação seguiu como rito a pré-análise, seguida da descrição analítica e interpretação inferencial. ${ }^{54} \mathrm{~A}$ figura 1 radiografa as duas últimas etapas.

Figura 1 - Descrição analítica e análise inferencial.

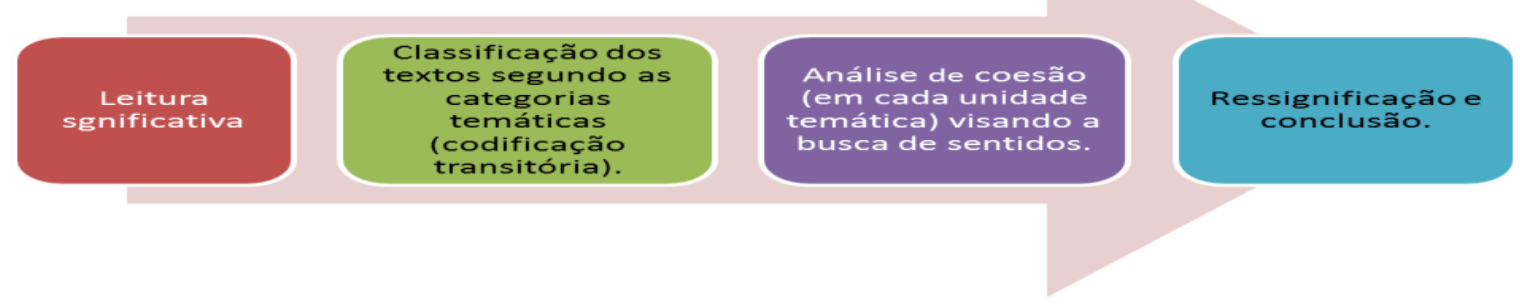

Fonte: elaborada pelas autoras.

A análise de coesão, realizada após alocação dos trechos destacados às categorias, visou à extração de possíveis significados. Sentido em que

Codificar significa associar marcadores a segmentos de dados que representam aquilo de que se trata cada um dos segmentos. A codificação refina os dados, classifica-os e nos fornece um instrumento para que assim possamos estabelecer comparações com outros segmentos de dados..$^{55}$

\footnotetext{
${ }^{53}$ HENRIQUES, Antônio; MEDEIROS, João Bosco. Metodologia na pesquisa jurídica. São Paulo: Atlas, 2017. ${ }^{54}$ MARTINS, Gilberto de Andrade. Estudo de casos: uma estratégia de pesquisa. São Paulo: Atlas, 2008.

${ }^{55} \mathrm{CHARMAZ}$, Kathy. A construção da teoria fundamentada: guia prático para análise qualitativa. Porto Alegre: Bookman, 2009, p. 16.
} 
A codificação, independente do método de procedimento, corresponde ao processo de desconstrução, reorganização e alocação dos dados coletados no campo em torno de temas centrais relevantes à interpretação do fenômeno investigado.

Os códigos compõem, portanto, o constructo teórico da pesquisa, obtido a partir das próprias demandas da investigação e representações de significado emergentes. Por essa razão, os textos subordinados a cada categoria de análise fazem sentido (coerência) no contexto da investigação, compondo o que se denomina unidade de significado. Assim, a categorização se refletiu os objetos teóricos e empíricos da pesquisa. ${ }^{56}$

A desconstrução da matéria-prima de análise calibrou o olhar das pesquisadoras, concentrando sua atenção no que, de fato, importa à solução da questão proposta (demandas teóricas e empíricas), promovendo movimentos sucessivos de ressignificação.

Os códigos, apresentados nesse estudo, tiveram origem na exploração dos acórdãos, entregando questões de interesse e de necessária atenção, norteando a seleção dos casos. Destaque-se que na análise qualitativa, coleta e análise se processam simultaneamente, característica distintiva de seus métodos.

0 processo de categorização foi conduzido com base nas seguintes fases: inventário de unidades temáticas necessárias a uma inferência melhor substanciada; classificação dessas unidades e, a partir dessa estrutura, a organização das categorias. ${ }^{57}$

Relativamente aos dados de entrada, o estudo em tela concentrou-se na perspectiva dos reclamantes (supostas vítimas de assédio), discursos de defesa e testemunhas do fenômeno, pois se entendeu que essas narrativas revelariam os elementos que, segundo os autores das ações, caracterizaram e definiram a conduta, revelando os comportamentos típicos. Realmente, os temas, nessa modalidade de análise categorial, emergem da exploração dos dados de pesquisa. Assim, definiu-se como categorias da análise de conteúdo:

- $\quad$ as faces e características do fenômeno;

- $\quad$ a repercussão da inatividade gerencial;

- $\quad$ as tipologias do assédio moral e suas consequências;

- $\quad$ as práticas gerenciais e.

- $\quad$ os limites do exercício do poder diretivo.

\footnotetext{
${ }^{56}$ BARDIN, Laurence. Análise de conteúdo. Lisboa: edições 70, 1977.

${ }^{57}$ GUERRA, Isabel Carvalho. Pesquisa qualitativa e análise de conteúdo: sentidos e formas de uso. Rio de Janeiro: Lucerna, 2006.
} 
0 processo de categorização move-se da transitoriedade das categorias à codificação convergente. Ao longo coleta, essas categorias denunciaram seu caráter provisório na medida em que as situações investigadas não somente coalesceram às categorias inicialmente propostas, mas também revelavam novas necessidades, norteando a investigação a sucessivas triagens temáticas. Os memorandos gerados nessa experiência de pesquisa foram integralmente transcritos na discussão de resultados, baseando-se nos citados códigos, produzindo como resultado imediato um adequado ajustamento e objetividade à interpretação dos dados evocados dos documentos primários. 0 quadro 2 resume o protocolo elaborado.

Quadro 2 - Protocolo de estudo de caso

\begin{tabular}{|c|c|}
\hline ELEMENTOS & DECISÕES DE PESQUISA \\
\hline Unidade-caso & Alegações de assédio moral levadas a juízo. \\
\hline Documento analisado & Acórdãos (oriundos de diferentes tribunais) \\
\hline Delimitação espacial e temporal & Não aplicável. \\
\hline Tipologia de coleta & Documental \\
\hline Temporalidade de coleta & Transversal \\
\hline $\begin{array}{l}\text { Critérios de inclusão (composição das } \\
\text { unidades-caso) }\end{array}$ & $\begin{array}{l}\text { O enquadramento na definição da violência objeto } \\
\text { da investigação e a densidade narrativa. }\end{array}$ \\
\hline Sistematicidade na seleção dos casos & $\begin{array}{l}\text { Seleção aleatória para evitar o viés de } \\
\text { caracterização, uma vez que esse seria um produto } \\
\text { relevante da investigação. }\end{array}$ \\
\hline $\begin{array}{l}\text { Critérios de decisão do quantum de casos } \\
\text { analisados }\end{array}$ & $\begin{array}{l}\text { - Substância e complexidade dos casos } \\
\text { - Relevância e significado } \\
\text { - Saturação teórica } \\
\text { - Atingimento dos objetivos propostos } \\
\text { Optou-se pela exploração intensa dos casos } \\
\text { selecionados (aqueles mais significativos) }\end{array}$ \\
\hline Método de análise de dados & Análise de conteúdo (categorial temática) \\
\hline Tipologia de categorias & $\begin{array}{l}\text { Semiestruturada, orientada pelas demandas de } \\
\text { análise e peculiaridades dos casos. }\end{array}$ \\
\hline $\begin{array}{l}\text { Categorias consideradas na análise dos casos } \\
\text { (unidade categórica) }\end{array}$ & $\begin{array}{l}\text { - Dimensões (faces) e características do } \\
\text { fenômeno } \\
\text { - Repercussão da inatividade gerencial } \\
\text { - Classificação do assédio moral e suas } \\
\text { consequências } \\
\text { - Práticas gerenciais } \\
\text { - Limites do exercício do poder diretivo }\end{array}$ \\
\hline
\end{tabular}

Fonte: elaborado pelas autoras.

Decidiu-se realizar a análise categorial temática por força do nível de sistematização e objetividade presentes em seu delineamento. Diferentemente de outros estudos, não se realizou qualquer contagem de adjetivos, substantivos, palavras ou ideias. A frequência, no âmbito da análise de conteúdo, geralmente tem como função atribuir peso àquele elemento, como uma medida de relevância (imparcialidade objetiva), proximidade ou distanciamento. 0 método de 
ISSN 1981-3694

(DOI): $10.5902 / 1981369437184$

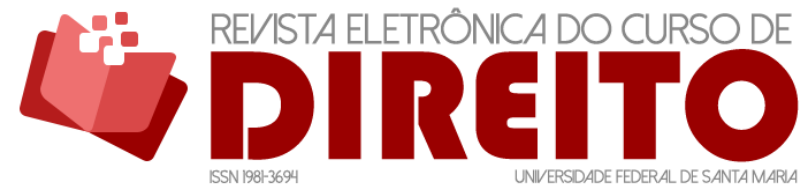

LIMITES DO PODER DIRETIVO DO GESTOR NAS RELAÇÕES DE TRABALHO: UMA ANÁLISE DE CASOS DE ASSEEDIO MORAL E PROFISSIONAL

YUMARA LÚCIA VASCONCELOS RAFAELA MARIA JOSÉ BERTINO

análise de conteúdo opera conteúdos e continentes, teores manifestos e latentes. Trata-se de uma hermenêutica orientada para inferência, orbitando entre a objetividade e a subjetividade, fazendo emergir no debate questões não aparentes.

\section{ANÁLISE E DISCUSSÃO DE RESULTADOS}

Priorizou-se, nesse estudo, destinar maior espaço a apresentação e discussão de resultados por se tratar de uma pesquisa empírica.

\subsection{Faces e características do fenômeno}

As situações narradas de assédio vertical descendente e misto revelam, em sua totalidade, os excessos praticados pelos agentes da conduta relativamente ao conceito de subordinação jurídica ínsitas nas relações trabalhistas. Esses 'excessos' ultrapassam os espaços interpessoais, demarcadores da intimidade do individuo, revelando doses variadas de crueldade e indiferença social. São condutas invasivas, cerceantes, ofensivas à honra do trabalhador, deliberadamente perversas, marcadas por exigências desarrazoadas, indignas e abusivas. A mera pressão de trabalho despropositada assume conotação de abuso no exercício do poder diretivo em razão de seu descabimento.

Os comportamentos de assédio perpassam, portanto, os níveis daqueles atribuídos à exigência profissional, descontração, jocosidade ou informalidade cotidiana, argumento de negação presente nos discursos de reclamadas. As agressões registradas assumiram abordagens variadas, sendo classificadas como segue: exposições desencorajadoras de desempenho; afirmações depreciativas à performance do (a) reclamante, apropriando-se de designações inadequadas e xingamentos; controle desproporcional às demandas da atividade; pressão psicológica exacerbada (descabida); expressão de desvalor à pessoa, inclinações, características físicas e escolhas, desviando a atenção, mitigando ou desvalorizando seu trabalho; ociosidade forçada (esvaziamento de funções) sem justificativa plausível ou o amparo de laudo médico atestando inaptidão; privação do trabalhador das condições necessárias ao exercício das atividades designadas (instrumentos de labor); submissão a práticas ritualísticas vexatórias; rigor excessivo (cobranças, exigências) e hostilidade no trato profissional; assédio crítico (críticas exageradas e imotivadas); ofensas dirigidas a familiares e pessoas ligadas, com o intuito de atingir o assediado; explosões emocionais dirigidas à pessoa, rispidez, grosserias; falsas 
ISSN 1981-3694

(DOI): $10.5902 / 1981369437184$

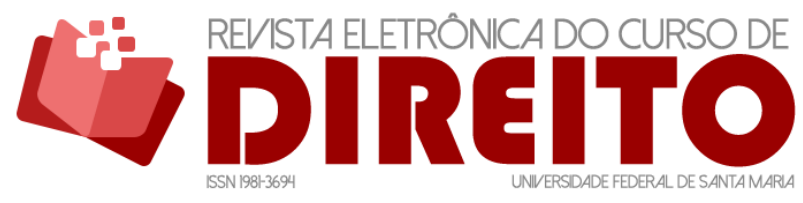

LIMITES DO PODER DIRETIVO DO GESTOR NAS RELAÇÕES DE TRABALHO: UMA ANÁLISE DE CASOS DE ASSEEDIO MORAL E PROFISSIONAL

YUMARA LÚCIA VASCONCELOS RAFAELA MARIA JOSÉ BERTINO

acusações visando macular a imagem do trabalhador; gestos obscenos; perseguições; ameaças de dispensa, ou de qualquer outra natureza; cerceamento; atribuição de alcunhas (conotação pejorativa); agressões verbais diversas; demonstração explícita de repulsa.

De fato, "Verifica-se esse aspecto humilhante pela pressão de se alcançar uma forte cadência produtiva, pela ameaça constante de demissão caso não alcance a meta determinada, pela maneira de suportar as ordens, pela contínua simplificação e fragmentação." 58

A análise dos acórdãos remeteu à conclusão de que a configuração da conduta reclama farta contextualização. Significa afirmar que é necessário posicionar a conduta em seu contexto (ambiente laboral, condições, atores e relações), atentando para os elementos que caracterizam o assédio moral, destacados nos pisados fundamentos doutrinários e entendimentos jurisprudenciais acerca da matéria. Identificou-se nas peças a presença dos seguintes elementos: pessoalidade; lesividade (caráter ofensivo, malignidade); prática de excessos na relação laboral; recorrência (incidência ao longo de parte ou todo o contrato de trabalho); intencionalidade (objetivos não profissionais); abordagem sistemática e organizada; indicativos de premeditação (planejamento); objetivos (da conduta) alheios àqueles ínsitos à relação profissional; prolongamento ou progressão da conduta ao longo do tempo; condutas estranhas às atividades contratadas; manipulação coletiva; conduta omissiva da administração; impessoalidade na relação laboral; prevalência de objetivos corporativos ligados exclusivamente a desempenho (estratégias de controle, dominação e exploração).

A pessoalidade, como traço caracterizador do assédio, relacionou-se às inclinações, preconceitos e postura do ofensor relativamente ao alvo das agressões (que pode ser uma ou mais pessoas). 0 fato de tais agressões serem dirigidas a um grupo determinado não afastou o requisito pessoalidade no entendimento dos tribunais, que diz respeito aos motivos do agressor.

A frequência das agressões mostrou-se significativo nessa análise, não obstante existam posições contrárias. Ocorre que o termo deriva da ação 'assediar' que remete a importunação, perseguição reiterada ou insistente, molestação, o que afasta o entendimento de que uma única e isolada ocorrência é suficiente para configurar o assédio moral.

\subsection{Repercussão da inatividade gerencial}

\footnotetext{
${ }^{58}$ GUNTER, Luiz Eduardo. 0 assédio moral no ambiente do trabalho: dano moral e/ou dano existencial? Incidências da reforma trabalhista. In: GUNTER, Luiz Eduardo. ALVARENGA, R. Z. de; SCHIO, Adriana Cavalcante de Souza. (Org). Reforma trabalhista: impacto e aplicação da lei n. 13.467/2017. São Paulo: Ltr, 2018, p. 40.
} 
A inatividade de gestores não os dispensa de responsabilidade legal. Verificou-se na análise empreendida que a omissão da administração ante aos excessos praticados no ambiente de trabalho constitui variável facilitadora de sua ocorrência, oferecendo respaldo às condutas nocivas, assentando e naturalizando a violência.

A conivência, ativa ou passiva, presente nos casos de assédio misto desafia o diagnóstico da conduta em razão do nível de encadeamento e formação das redes informais de relacionamento; igualmente, oferece contraponto relevante à dialética simplificadora que restringe o fenômeno aos atores 'vítima-agressor'.

Detecta-se, contudo, na doutrina, posicionamento contrário à existência da modalidade de assédio misto. A justificativa para esse entendimento prender-seia ao fato de que em uma empresa é grande o número de pessoas envolvidas indiretamente com o assédio moral. ${ }^{59}$

As organizações se constituem por meio de suas culturas e paradigmas decorrentes. Os relacionamentos e o ambiente de trabalho refletem esses elementos. Dessa realidade decorre que ambientes permissivos são facilitadores de abusos. Essa afirmação encontrou respaldo na literatura que trata sobre o fenômeno, presente nos autores Valadão Júnior e Heinzmann ${ }^{60}$. Nessa direção de pensamento, pode-se afirmar que existe uma correspondência social entre a duração do assédio e comportamentos de omissão, alheamento consciente, estilo laissez fair de gestão, ou mesmo, da coação dos pares. Essa relação biunívoca enseja a banalização desses abusos, prolongando sofrimento e o status de exclusão das vítimas. A conivência, ativa ou passiva, afigura-se como a principal variável determinante do fenômeno.

Os conformistas seriam os espectadores que não se envolvem diretamente na ação perversa, mas não ficam isentos de responsabilidade porque nada fazem para frear a violência desencadeada pelo sujeito perverso (conformistas passivos). Outras vezes acontece de se manifestarem ativamente, favorecendo claramente a ação do agressor (conformistas ativos). Esses espectadores, embora pratiquem o mobbing, não seriam considerados adversários diretos da vítima. ${ }^{61}$

\footnotetext{
59 GUNTER, Luiz Eduardo. 0 assédio moral no ambiente do trabalho: dano moral e/ou dano existencial? Incidências da reforma trabalhista. In: GUNTER, Luiz Eduardo. ALVARENGA, R. Z. de; SCHIO, Adriana Cavalcante de Souza (Org). Reforma trabalhista: impacto e aplicação da lei n. 13.467/2017. São Paulo: Ltr, 2018, p. 45.

${ }^{60}$ VALADÃO JÚNIOR, Valdir Machado; HEINZMANN, Lígia Maria. Assédio Moral: análise do tem por meio de uma bibliometria. Revista Eletrônica Científica do CRA-PR-RECC, v. 6, n. 1, p. 1-20, 2019. Disponível em: http://recc.cra-pr.org.br/index.php/recc/article/view/127 Acesso em 10 jul. 2020.

${ }_{61}$ GUNTER, Luiz Eduardo. 0 assédio moral no ambiente do trabalho: dano moral e/ou dano existencial? Incidências da reforma trabalhista. In: GUNTER, Luiz Eduardo. ALVARENGA, R. Z. de; SCHIO, Adriana Cavalcante de Souza. (Org). Reforma trabalhista: impacto e aplicação da lei n. 13.467/2017. São Paulo: Ltr, 2018, p. 45.
} 
ISSN 1981-3694

(DOI): $10.5902 / 1981369437184$

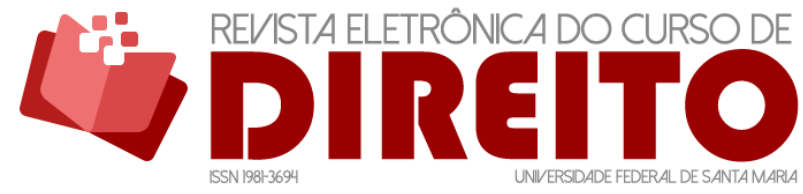

LIMITES DO PODER DIRETIVO DO GESTOR NAS RELAÇÕES DE TRABALHO: UMA ANÁLISE DE CASOS DE ASSEEDIO MORAL E PROFISSIONAL

YUMARA LÚCIA VASCONCELOS RAFAELA MARIA JOSÉ BERTINO

Do cotejo entre as demandas trabalhistas e a prática gerencial revela-se um ambiente de trabalho nem sempre saudável, o qual respalda e facilita a ocorrência de diferentes formas de violência. Dessume-se, da análise dos acórdãos, que a conivência é a principal mantenedora da conduta, cunhando um status de desigualdade e exclusão.

\subsection{Tipologia do assédio}

A ausência de pessoalidade nos casos de assédio não desnatura a conduta abusiva, muito menos afasta seus efeitos, mas reclama intervenção específica. Esta análise revela a importância de tratar separadamente o assédio moral daquele profissional, uma vez que o componente 'pessoalidade' é tido como essencial à caracterização do assédio moral.

0 assédio profissional, embora conceitualmente tratado como 'moral', não menos prejudicial à dignidade do trabalhador, é desprovido de pessoalidade porque se baseia em motivos empresariais e decorrem da precarização das relações de trabalho e formas emergentes de organização da produção, ou mesmo, de modelos de gestão. A impessoalidade se impôs como critério distintivo em alguns dos casos analisados, nos quais se visou é essencialmente a superutilização da mão de obra a serviço do capital.

0 assédio organizacional relaciona-se a um conjunto de práticas reiteradas, inseridas nas estratégias e métodos de gestão, por meio de pressões, humilhações e constrangimentos, para que sejam alcançados determinadas finalidades empresariais ou institucionais. ${ }^{62}$

Ao estabelecer controle sobre o corpo, conduta e tempo do trabalhador, por meio dos discursos de maximização de desempenho, as organizações reduzem o custo da mão de obra, incrementando a produtividade per capta, e, por conseguinte, seus lucros. Por essa lógica de exploração, a omissão nos casos de assédio profissional é estratégica.

O quadro 2 apresenta os elementos caracterizadores dessa modalidade de assédio, igualmente, as condutas que esse modus alberga. A análise dos casos ensejou a conclusão de que esses traços distintivos conferiram às agressões contornos mais específicos, embora os resultados tenham sido igualmente nefastos. "O assédio organizacional, ou institucional, gerados pelas

\footnotetext{
${ }^{62}$ GUNTER, Luiz Eduardo. 0 assédio moral no ambiente do trabalho: dano moral e/ou dano existencial? Incidências da reforma trabalhista. In: GUNTER, Luiz Eduardo. ALVARENGA, R. Z. de; SCHIO, Adriana Cavalcante de Souza (Org). Reforma trabalhista: impacto e aplicação da lei n. 13.467/2017. São Paulo: Ltr, 2018, p. 46.
} 
novas formas de organização do trabalho, desmobiliza e elimina do mercado de trabalho um número imensurável de trabalhadores." 63

O assédio moral, em razão de suas características, especialmente seu caráter 'pessoal', apresentou um espectro maior de condutas. Por consequência, o assédio profissional é usualmente blindado pela necessidade de manutenção do trabalho e pelas falas que recomendam ou enaltecem determinados modelos de gestão. Na totalidade das situações jurídicas, as demandas patronais, as abordagens extrapolaram os limites da licitude, impostos por padrões de razoabilidade.

No intento de diferenciar o assédio moral e profissional, encontrou convergências, a exemplo da violação de direitos fundamentais e o dano moral consequente. A diferença reside no objetivo subjacente às estratégias. São os objetivos que animam a violação. Inclusive, o assédio moral, em razão de suas características, pode basear-se ou se estabelecer em enfermidades ou predisposições do agente.

Quadro 2 - Modalidades de assédio: características e agressões típicas.

\begin{tabular}{|c|c|c|}
\hline $\begin{array}{l}\text { MODALIDADES DE } \\
\text { ASSÉDIO }\end{array}$ & ASSÉDIO MORAL & ASSÉDIO PROFISSIONAL \\
\hline Traços distintivos & $\begin{array}{l}\text { - Pessoalidade; } \\
\text { - } \quad \text { Lesividade (caráter ofensivo, malignidade); } \\
\text { - Prática de excessos na relação laboral; } \\
\text { - } \quad \text { Frequência, recorrência (incidência ao longo de } \\
\text { parte ou todo o contrato de trabalho); } \\
\text { - Intencionalidade (objetivos não profissionais); } \\
\text { - } \quad \text { Abordagem sistemática e organizada; } \\
\text { - Premeditação (planejamento); } \\
\text { - Objetivos (da conduta) alheios àqueles ínsitos à } \\
\text { relação profissional; } \\
\text { - Prolongamento ou progressão da conduta ao } \\
\text { longo do tempo; } \\
\text { - Condutas estranhas às atividades contratadas } \\
\text { - Manipulação coletiva, } \\
\text { continuidade da agressão; } \\
\text { - Conduta omissiva da administração. }\end{array}$ & $\begin{array}{l}\text { - Impessoalidade no trato e } \\
\text { relação laboral; } \\
\text { - Lesividade (caráter ofensivo, } \\
\text { malignidade); } \\
\text { - Prática de excessos na relação } \\
\text { laboral; } \\
\text { - Recorrência (incidência ao } \\
\text { longo de parte ou todo o contrato } \\
\text { de trabalho); } \\
\text { - Abordagem sistemática e } \\
\text { organizada; } \\
\text { - Premeditação (planejamento); } \\
\text { - Prolongamento ou progressão } \\
\text { da conduta ao longo do tempo; } \\
\text { - Prevalência de objetivos } \\
\text { corporativos ligados } \\
\text { exclusivamente a desempenho } \\
\text { (estratégias de controle, } \\
\text { dominação e exploração). }\end{array}$ \\
\hline
\end{tabular}

${ }^{63}$ GUNTER, Luiz Eduardo. 0 assédio moral no ambiente do trabalho: dano moral e/ou dano existencial? Incidências da reforma trabalhista. In: GUNTER, Luiz Eduardo. ALVARENGA, R. Z. de; SCHIO, Adriana Cavalcante de Souza (Org). Reforma trabalhista: impacto e aplicação da lei n. 13.467/2017. São Paulo: Ltr, 2018, p. 46. 


\begin{tabular}{|c|c|c|}
\hline Agressões típicas & $\begin{array}{l}\text { - Pressão psicológica exacerbada (descabida); } \\
\text { - Expressão de desvalor à pessoa, inclinações, } \\
\text { características físicas e escolhas, desviando a } \\
\text { atenção, mitigando ou desvalorizando seu } \\
\text { trabalho; } \\
\text { - Desmoralização pública; } \\
\text { - Ociosidade forçada (esvaziamento de funções) } \\
\text { sem justificativa plausível ou o amparo de laudo } \\
\text { médico atestando inaptidão; } \\
\text { - Privação do trabalhador das condições } \\
\text { necessárias ao exercício das atividades designadas } \\
\text { (instrumentos de labor) por motivos não } \\
\text { aparentes; } \\
\text { - Submissão a práticas ritualísticas vexatórias tão } \\
\text { somente para atingir a pessoa; } \\
\text { - Hostilidade no trato profissional em razão de } \\
\text { diferenças pessoais; } \\
\text { - Assédio crítico (críticas exageradas e } \\
\text { imotivadas); } \\
\text { - Ofensas dirigidas a familiares e pessoas ligadas, } \\
\text { com o intuito de atingir o assediado; } \\
\text { - Explosões emocionais dirigidas à pessoa, } \\
\text { rispidez, grosserias; } \\
\text { - Falsas acusações visando macular a imagem do } \\
\text { trabalhador; } \\
\text { - Gestos obscenos; } \\
\text { - Perseguições; ameaças de dispensa, ou de } \\
\text { qualquer outra natureza; Cerceamento; } \\
\text { - Atribuição de alcunhas (conotação pejorativa); } \\
\text { - Demonstração explícita de repulsa e desdém. }\end{array}$ & $\begin{array}{l}\text { - Exposições desencorajadoras de } \\
\text { desempenho; } \\
\text { - Afirmações depreciativas à } \\
\text { performance do (a) trabalhador } \\
\text { (a), apropriando-se de designações } \\
\text { inadequadas e xingamentos; } \\
\text { - Controle desproporcional às } \\
\text { demandas da atividade; } \\
\text { - Pressão psicológica exacerbada } \\
\text { (descabida); do trabalhador das } \\
\text { - Privação do } \\
\text { condições necessárias ao exercício } \\
\text { das atividades designadas } \\
\text { (instrumentos de labor); } \\
\text { - Rigor excessivo (cobranças, } \\
\text { exigências) e hostilidade no trato } \\
\text { profissional; } \\
\text { - Assédio crítico (críticas } \\
\text { exageradas e imotivadas); } \\
\text { - Prática de rituais vexatórios } \\
\text { mascarados como 'dinâmicas de } \\
\text { grupo', visando provocar } \\
\text { desempenhos superiores. }\end{array}$ \\
\hline
\end{tabular}

Fonte: Elaborado pelas autoras.

0 controle do trabalho é um dos braços da gestão. 0 estabelecimento de metas se insere no escopo do exercício desse controle, desde que não se operacionalize de forma abusiva. 0 abuso se configura quando desrespeita diretivas contratuais, normativas e regimentais. Em geral, a conduta se define como assédio profissional porque tem origem em objetivos corporativos. A cobrança desarrazoada de metas remete à consideração de que o assédio profissional se desenvolve predominantemente em ambientes produtivistas, em que a competição de mercado é internalizada à organização, naturalizada nas relações de trabalho constituídas. 0 assédio profissional revela a latência autoritária presente nas organizações do trabalho e desumanização crescente dessas relações.

Essa análise encaminhou ao entendimento de que as características da conduta definem as estratégias de assédio, moral ou profissional. Constatou-se ainda, na investigação das tipologias, que o assédio praticado isoladamente pode evoluir para um assédio misto, aquele vertical e horizontal, em razão da adesão e conivência ativa ou passiva dos pares, movidos por propósitos pessoais ou meramente de exploração (assédio profissional). A conivência passiva de 
colegas, assim como a omissão da administração, respalda a conduta, dando ensejo à sua continuidade, até mesmo à evolução das agressões.

\subsection{Consequências do assédio moral}

Conduta vertical ou horizontal, o assédio moral atinge frontalmente a pessoa. A violência psicológica tem produtos não acessíveis a terceiros (efeitos extrapatrimoniais), razão pela qual sua percepção e comprovação se esbarram em dificuldades de ordem prática. Reações como angústia, tristeza, aflição não são ponderáveis. 0 reconhecimento do dano moral é a resposta punitiva e pedagógica do Direito à violência.

As consequências descritas nos processos foram categorizadas como segue: instabilidade psicológica; desconforto social; sentimento de menos valia (baixa autoestima); sofrimento íntimo; renúncia de identidade; adoecimento físico (somatização); desmotivação crescente e, por conseguinte, o desligamento provocado. Esse panorama ressalta o quão o assédio moral é lesivo, atingindo não somente o alvo das agressões, mas igualmente, as células de trabalho e aquela familiar.

$\mathrm{Na}$ progressão, conforme denunciam os relatos, o agressor passa a comandar a vida emocional da pessoa agredida, ferindo-lhe a autodeterminação. Embora as narrativas se concentrem na repercussão da conduta sobre a vida do trabalhador, os efeitos podem, por lógica, ser naturalmente ampliados a outros níveis, organizacional e econômico. Relativamente às sanções no âmbito dos tribunais, não se pode afirmar que as indenizações e multas administrativas cabíveis nesses casos afetem a saúde financeira das empresas sucumbidas em processo. $\mathrm{O}$ arbitramento de valores não respeita um critério baseado no desempenho financeiro do negócio.

As indenizações apresentam duas finalidades precípuas: a de reparação da vítima de dano e outra pedagógica. Entretanto, os valores eventualmente insignificantes afiguram-se prejudiciais à consecução do segundo objetivo. De qualquer sorte,

[...] um ambiente de trabalho em que se praticam atos abusivos tende a apresentar resultados produtivos menores, por conta da ineficiência da gestão de pessoas. Ainda, o elevado índice de turn over dificulta a estabilidade produtiva da empresa, que precisará arcar com custos elevados na substituição de empregados e sua necessária qualificação para o trabalho. ${ }^{64}$

\footnotetext{
${ }^{64}$ MIKOS, Nadia Regina de Carvalho; VILLATORE, Marco Antônio César. Poderes do empregador: do uso ao abuso e suas consequências socioeconômicas. In: GARCIA, Gustavo Filipe Barbosa. ALVARENGA, Rúbia
} 
Os casos de assédio comprovados em juízo se traduzem em diferentes parcelas de gastos: despesas médicas, indenizações, honorários advocatícios e aqueles destinados a processos seletivos. Todas as partes envolvidas vivenciam perdas de natureza e níveis distintos. Essa realidade coloca em relevo a necessidade de se realizar pesquisas visando analisar a efetividade das medidas processuais em sua tutela inibitória da conduta, especialmente nos casos de reincidência.

\subsection{Sujeitos vulneráveis}

Não obstante se reconheça a vulnerabilidade dos empregados na iniciativa privada, a estabilidade dos servidores públicos não afasta ocorrências. Esse dado fomenta reflexão acerca dos motivos e fatores que influenciam ou fomentam a conduta. Identificou-se como sujeitos vulneráveis ao assédio moral: trabalhadores homossexuais, negros, mulheres e pessoas pouco escolarizadas ocupando funções de baixa remuneração.

\subsection{Poder e práticas gerenciais}

A análise realizada remete a uma reflexão atenta acerca do sentido e dimensão da subordinação jurídica presente nas relações de trabalho, tendo em vista que a liberdade desse poder não implica submissão irrestrita ou renúncia de identidade.

As atividades da administração preveem as funções de liderança, organização, alocação de recursos, coordenação, planejamento, delegação de tarefas, regulamentação, disciplina e fiscalização. Desta maneira, as ações de gestão adstritas a esses limites são resguardadas pela legislação trabalhista vigente.

O exercício do poder de mando não alberga condutas que violam a dignidade do indivíduo. A ausência de queixas não implica aceitação dos comportamentos ou autoconivência, podendo comunicar tão somente uma reação de evitação ao trauma vivenciado, igualmente, temor à retaliação.

A intimidade deve ser resguardada nas relações de trabalho. Os casos de assédio moral desrespeitam esse território personalíssimo. Ocorre que o poder diretivo torna latente a

Zanotelli de. Direito do trabalho e direito empresarial: sob o enfoque dos direitos fundamentais. São Paulo : LTr, 2015, p. 85 
ISSN 1981-3694

(DOI): $10.5902 / 1981369437184$

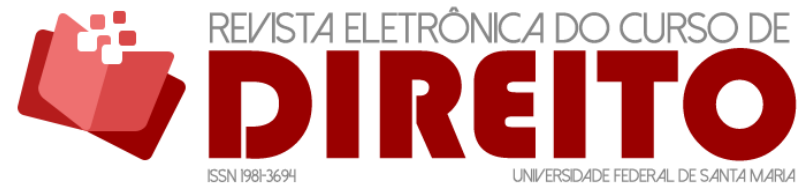

LIMITES DO PODER DIRETIVO DO GESTOR NAS RELAÇÕES DE TRABALHO: UMA ANÁLISE DE CASOS DE ASSEEDIO MORAL E PROFISSIONAL

YUMARA LÚCIA VASCONCELOS RAFAELA MARIA JOSÉ BERTINO

evidência desses abusos contingentes, razão pela qual é exortado como justificativa de comportamentos.

As narrativas constantes nos alegados casos de assédio moral revelam as minorias formadas a partir de suas inclinações políticas e posições identitárias, bem como as configurações raciais e religiosas que emergem na realidade organizacional.

As organizações são fragmentos da sociedade, dos quais se sobrevalem a solidariedade e o senso de pertencimento, mas igualmente, desigualdade, intolerância, discriminação e abusos. A conduta de assédio moral desvela um cenário de exclusão e negação da existência de minorias não aceitas, estabelecendo-se ao reverso dos direitos e garantias legais.

\section{CONCLUSÃO}

Os atores da relação laboral se esbarram em limites, os quais, quando violados, podem encadear danos às partes, especialmente à saúde do trabalhador, desarmonizando o ambiente de trabalho. Esses limites, entretanto, estão relacionados às demandas do serviço prestado. Implica dizer que o que não é necessário à realização do trabalho, em determinadas condições, pode ser configurado como excesso, ensejando a reclamatória de dano moral.

A conduta de assédio moral no trabalho comporta diferentes formas de excessos no exercício profissional, todas decorrentes da exorbitância do poder de mando de empregadores e seus prepostos (gestores). Ocorre que na consecução do poder diretivo, também denominado de poder de mando ou de gestão, está adstrito à seara profissional. As atividades de gestão não alcançam o território da intimidade dos pares, aquelas que são estranhas à relação contratual de trabalho firmada. Assim, esse poder, que alcança toda a organização, não possui conotação invasiva, preservando-se na relação de trabalho as liberdades e intimidade do trabalhador.

Empregador e gestor têm a liberalidade (restrita) para propor acordos sobre aspectos não contemplados em contrato (discricionariedade unilateral), porém, desde que não afronte ou viole a dignidade do trabalhador. Essa faculdade, inclusive, é amplamente tratada na doutrina e denominada de jus variandi. Discricionariedade não implica arbitrariedade ou abuso.

O controle patrimonial é natural, todavia, a apropriação inadequada da tecnologia ou mesmo de prerrogativas funcionais podem ferir o direito à intimidade e privacidade do trabalhador. 
ISSN 1981-3694

(DOI): $10.5902 / 1981369437184$

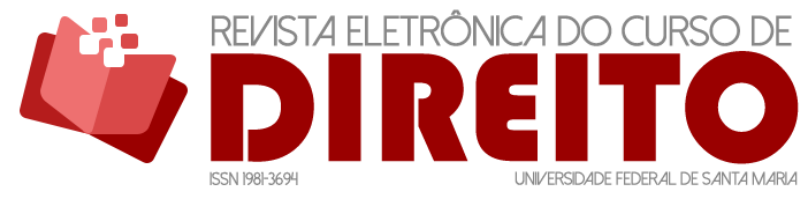

LIMITES DO PODER DIRETIVO DO GESTOR NAS RELAÇÕES DE TRABALHO: UMA ANÁLISE DE CASOS DE ASSEEDIO MORAL E PROFISSIONAL

YUMARA LÚCIA VASCONCELOS RAFAELA MARIA JOSÉ BERTINO

A legislação trabalhista tem como missão impor limites ao exercício desse poder em favor do sujeito hipossuficiente da relação (trabalhador). O Direito do Trabalho tem um importante papel na sociedade, que é o de realizar a justiça social e promover a democracia, retificando as desigualdades reinantes no mundo do trabalho.

A subordinação jurídica ínsita aos contratos de trabalho não implica sujeição absoluta, uma vez que os direitos de personalidade são tutelados pelo ordenamento jurídico brasileiro. Os casos analisados denunciam, em sua totalidade, alheamento a essa diretriz, que é elementar a uma eficaz gestão de pessoas.

Apesar de ensejar o equilíbrio entre os agentes na relação contratual de emprego, o Direito do trabalho, a olhos equivocados, é visto como a especialidade que apresenta inclinação protecionista relativamente ao laborista. Essa preconcepção, entretanto, não tem inibido a ocorrência de casos de assédio, moral e profissional.

Os desafios atrelados à responsabilização civil dizem respeito à caracterização da ilicitude da conduta, lesão moral (dano à honra) e o nexo de casualidade 'dano-conduta' (requisitos legais configurantes). A comprovação da conduta autoriza que seja decretada prontamente a rescisão indireta (oblíqua) do contrato de trabalho, além do ônus da indenização.

Constitui obrigação do empregador, extensiva aos seus prepostos, viabilizar um ambiente de trabalho saudável à convivência social, incentivando condutas éticas e respeitosas, coibindo abusos corporativos.

$\mathrm{O}$ assédio moral, do ponto de vista legal, representa uma violação clausular que afronta a dignidade da pessoa humana, violando o princípio jurídico da boa-fé contratual. Sem a pretensão de generalizar, os casos de assédio analisados revelaram características comuns aderentes aos entendimentos doutrinários aduzidos na revisão de literatura; ao mesmo tempo em que entregaram uma variedade de formas de materialização da conduta, com finalidades pessoais e empresariais. Dessa constatação culminou a necessidade de se classificar os casos de assédio no ambiente de trabalho em moral e profissional.

0 assédio moral tem como característica distintiva a pessoalidade. Os objetivos do agressor são pessoais, embora a agressão se dê no ambiente de trabalho. Já o assédio profissional carrega propósitos que não são da 'pessoa'. O algoz ou ofensor direto enquadra-se mais como instrumento de um modelo de produção 'pseudo-justificador', do que como agente autônomo da ação. Essas características influenciam o modus da conduta. Nos casos analisados, identificaram-se indícios de uma relação direta entre tipo de assédio e condutas típicas. 
ISSN 1981-3694

(DOI): $10.5902 / 1981369437184$

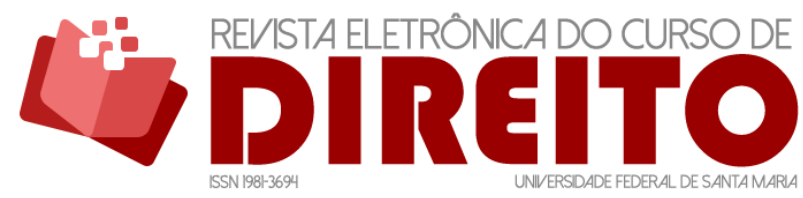

LIMITES DO PODER DIRETIVO DO GESTOR NAS RELAÇÕES DE TRABALHO: UMA ANÁLISE DE CASOS DE ASSÉDIO MORAL E PROFISSIONAL

YUMARA LÚCIA VASCONCELOS RAFAELA MARIA JOSÉ BERTINO

Embora se identifique uma variedade de estratégias para mascaramento da conduta, seus efeitos tornam-se visíveis no decurso e progressão da violência, tornando o ambiente de trabalho um 'lugar de sofrimento'. Parte dos abusos ou excessos verificados no mundo do trabalho atenta contra o patrimônio moral e emocional do trabalhador, posto que compromete sua higidez física e mental. Em face às dificuldades práticas de diagnóstico, controle e prevenção, o tema segue fecundo em recortes e problematizações.

\section{REFERÊNCIAS}

ABIB, José Antônio Damásio. Epistemologia, transdisciplinaridade e método. Psicologia: teoria e pesquisa, v. 12, n. 3, p. 219-229, 1996.

ACKERMAN, Sebastián Erneston; COM, Sérgio Luis. Metodología de la investigación. Buenos Aires, AR: Ediciones del Aula Taller, 2013.

ALKIMIN, Maria Aparecida. Assédio moral na relação de trabalho. Curitiba: Juruá Editora, 2013.

BARDIN, Laurence. Análise de conteúdo. Lisboa: edições 70, 1977.

BARROSO, Luis Roberto; DE BARCELLOS, Ana Paula. O começo da história. A nova interpretação constitucional e o papel dos princípios no direito brasileiro. Revista de direito administrativo, v. 232, p. 141-176, abr./jun., 2003. Disponível em:

http://bibliotecadigital.fgv.br/ojs/index.php/rda/article/view/45690 Acesso em 10 maio 2017.

BELTRÃO, Silvio Romero. Direitos da personalidade. São Paulo: Atlas, 2014.

CAMARGO, Jota. Princípio da igualdade: efetividade dos direitos, liberdades e garantias das minorias e dos excluídos. In: DONIZETTI, Elpídio; GARBIN, Rosana Broglio; OLIVEIRA, Thiago de Diversos enfoques do princípio da igualdade. Belo Horizonte: Editora Fórum, 2014.

CARDANO, Mario. Manual de pesquisa qualitativa: a contribuição da teoria da argumentação. Petrópolis: Vozes, 2017.

CASTRO, Cláudio Roberto Carneiro de. 0 que você precisa saber sobre assédio moral nas relações de emprego: doutrina, jurisprudência e casos concretos atuais. São Paulo: LTR, 2014.

CHARMAZ, Kathy. A construção da teoria fundamentada: guia prático para análise qualitativa. Porto Alegre: Bookman, 2009.

CUNICO, Miriam Machado. Saindo do silêncio: o assédio moral quase destruiu minha vida. Curitiba: Concep, 2014.

DELGADO, Mauricio Goldinho. Relação de emprego e relações de trabalho: a retomada do expansionismo do Direito do trabalho. In: SENA, Adriana Goulart de; DELGADO, Gabriela Neves; 
NUNES, Raquel Portugal. Dignidade humana e inclusão social: caminhos para a efetividade do Direito do Trabalho no Brasil. São Paulo: LTr, 2010, p.17-33.

DENZIN, Norman Kent; LINCOLN, Yvonna Sessions. Handbook of qualitative research. Sage publications, inc., 1994.

EINARSEN, Ståle. The nature, causes and consequences of bullying at work: the Norwegian experience. Perspectives Interdisciplinaires Sur le Travail et la Santé, v. 7, n. 3, 2005.

FOWLER JÚNIOR, Floyd. Pesquisa de levantamento. Campinas, SP: Penso, 2011.

FREITAS, Maria Éster de. Existe uma saúde moral nas organizações?. Organizações \& Sociedade, v. 12, n. 32, p. 13-27, 2005. Disponível em:

https: / / www.scielo.br/scielo.php?script=sci_arttext\&pid=S1984-92302005000100001 Acesso em 10 maio 2017

GARCÍA, Eusebio Fernández. Dignidad humana y ciudanía cosmopolita. Madrid: Editorial Dykinson, 2001.

GUERRA, Isabel Carvalho. Pesquisa qualitativa e análise de conteúdo: sentidos e formas de uso. Rio de Janeiro: Lucerna, 2006.

GUERRA, Sidney; EMERIQUE, Lílian Márcia Balmant. O princípio da dignidade da pessoa humana e o mínimo existencial. Revista da Faculdade de Direito de Campos, v. 7, n. 9, p. 379-398, 2006. Disponível em: http://fdc.br/Arquivos/Mestrado/Revistas/Revista09/Artigos/Sidney.pdf. Acesso em 20 maio 2017.

GUIMARÃES, Liliana Andolpho Magalhães; RIMOLI, Adriana Odalia. "Mobbing" (assédio psicológico) no trabalho: uma síndrome psicossocial multidimensional. Psicologia: Teoria e Pesquisa, Brasília, v. 22, n. 2, p. 183-191, ago. 2006. Disponível em: https://www.scielo.br/scielo.php?pid=S010237722006000200008\&script=sci_abstract\&tlng=pt. Acesso em 20 maio 2017.

GUNTER, Luiz Eduardo. $O$ assédio moral no ambiente do trabalho: dano moral e/ou dano existencial? - Incidências da reforma trabalhista. In: GUNTER, Luiz Eduardo; ALVARENGA, Rúbia Zanotelli de; SCHIO, Adriana Cavalcante de Souza (Org). Reforma trabalhista: impacto e aplicação da lei n. 13.467/2017. São Paulo: Ltr, 2018, p. 40.

GUNTHER, Luiz Eduardo. O direito da personalidade e suas repercussões na atividade empresarial. In: Gunther, Luíz Eduardo (Coord.). Tutela dos direitos da personalidade na atividade empresarial. Curitiba: Juruá, 2008.

HENRIQUES, Antonio; MEDEIROS, João Bosco. Metodologia na pesquisa jurídica. São Paulo: Atlas, 2017.

HIRIGOYEN, Marie-France. Todo lo que hay que saber sobre el acoso moral en el trabajo. Barcelona: Paidós Contextos, p. 21-44, 2014. 
LOPES, Maurício Antonio Ribeiro. Princípios políticos do Direito Penal. São Paulo: Revista dos tribunais, 1999, p. 257.

LORENTE, Marisa Bosqued. Mobbing: como prevenir y superar el acoso psicológico. Barcelona: Paidós Contextos, 2005.

MARTINS, Gilberto de Andrade. Estudo de casos: uma estratégia de pesquisa. São Paulo: Atlas, 2008.

MERRIAM, Sharan B. Qualitative Research and Case Study Applications in Education. Revised and Expanded from Case Study Research in Education. Jossey-Bass Publishers, 350 Sansome St, San Francisco, CA 94104, 1998.

MIKOS, Nadia Regina de Carvalho; VILLATORE, Marco Antônio César. Poderes do empregador: do uso ao abuso e suas consequências socioeconômicas. In: GARCIA, Gustavo Filipe Barbosa; ALVARENGA, Rúbia Zanotelli de. Direito do trabalho e direito empresarial: sob o enfoque dos direitos fundamentais. São Paulo : LTr, 2015.

MINAYO, Maria Cecília de Souza. Análise qualitativa: teoria, passos e fidedignidade. Revista Ciência \& Saúde Coletiva, v. 17, n. 3, p. 621-626, 2012. Disponível em:

https: / / www.scielo.br/scielo.php?pid=S141381232012000300007\&script=sci_abstract\&tlng=pt. Acesso em: 20 maio 2017.

NEGRI, Sergio. Mobbing: nove storie di lavoro e ingiustizia quotidiana. Itália: Libreria Universitaria, 2011.

OLMOS, Cristina Paranhos. Direitos da personalidade nas relações de trabalho: limitação, relativização e disponibilidade. São Paulo: LTr, 2017.

PAVELSKI, Ana Paula. Relação de emprego e direitos de personalidade: por um emprego digno. In: Gunther, Luíz Eduardo (Coord.). Tutela dos direitos da personalidade na atividade empresarial. Curitiba: Juruá, 2008.

PITHAN, Lívia Haygert. A dignidade humana como fundamento jurídico das 'ordens de não ressurreição'. Porto Alegre: EDIPUCS, 2004.

RAYNAUT, Claude. Dicotomia entre ser humano e natureza: paradigma fundador do pensamento científico. In: PHILIPPI Jr, Arlindo; FERNANCES, Valdir. Práticas da interdisciplinaridade no ensino e pesquisa. Barueri, SP: Manole, 2015.

ROJO, José Vicente; CERVERA, Ana María. Mobbing o acoso laboral. Madrid: Tébar, p 21-60 2005.

SANTOS, Cibele Carneiro da Cunha Macedo. Assédio moral e a responsabilidade civil empresarial. In: GARCIA, Gustavo Filipe Barbosa; ALVARENGA, Rúbia Zanotelli de. Direito do trabalho e Direito empresarial. São Paulo: LTr, 2015.

SILVA, José Afonso da. A dignidade da pessoa humana com valor supremo da democracia. Revista de direito administrativo, v. 212, p. 89-94, 1998. Disponível em: 
http://bibliotecadigital.fgv.br/ojs/index.php/rda/article/view/47169/45637. Acesso em 10 maio 2017.

SRIVASTAVA, Aashish; THOMSON, Stanley Bruce. Framework analysis: a qualitative methodology for applied policy research, JOAAG-Journal of Administration \& Governance. V. 4, n 2, p. 7279, 2009.

THORNE, Sally. Data analysis in qualitative research. Evidence based nursing, v. 3, n. 3, p. 6870, 2000. Disponível em: https://ebn.bmj.com/content/ebnurs/3/3/68.full.pdf. Acesso em 10 maio 2017.

VALADÃO JÚNIOR, Valdir Machado; HEINZMANN, Lígia Maria. Assédio Moral: análise do tem por meio de uma bibliometria. Revista Eletrônica Científica do CRA-PR-RECC, v. 6, n. 1, p. 1-20, 2019. Disponível em: http://recc.cra-pr.org.br/index.php/recc/article/view/127 Acesso em 10 jul. 2020.

VASCONCELOS, Yumara Lúcia. Assédio moral nos ambientes corporativos. Cadernos EBAPE-BR, Rio de Janeiro, v. 13, n. 4, p. 821-851, 2015. Disponível em: https://www.scielo.br/pdf/cebape/v13n4/1679-3951-cebape-13-04-00821.pdf. Acesso em 10 maio 2017.

Recebido em: 06.03.2019 / Revisões requeridas em: 18.06.2020 / Aprovado em: 18.09.2020 / Publicado em: 22.04.2021

\section{COMO FAZER REFERÊNCIA AO ARTIGO (ABNT):}

VASCONCELOS, Yumara Lúcia; BERTINO, Rafaela Maria José. Limites do poder diretivo do gestor nas relações de trabalho: uma análise de casos de assédio moral e profissional. Revista Eletrônica do Curso de Direito da UFSM, Santa Maria, RS, v. 15, n. 3, 2020, set./dez. ISSN 1981-3694.

DOI: http://dx.doi.org/10.5902/1981369437184. Disponível em:

https://periodicos.ufsm.br/revistadireito/article/view/37184 Acesso em: dia mês. ano.

Direitos autorais 2020 Revista Eletrônica do Curso de Direito da UFSM

Editores responsáveis: Rafael Santos de Oliveira e Angela Araujo da Silveira Espindola

Esta obra está licenciada com uma Licença Creative Commons Atribuição-NãoComercial-SemDerivações 4.0 Internacional.

\section{SOBRE AS AUTORAS}

\section{YUMARA LÚCIA VASCONCELOS}

Professora associada do curso de Administração da UFRPE e docente permanente do PPGDH/UFPE - Programa de pósgraduação em Direitos Humanos. Criadora e editora - gerente do periódico "Interdisciplinaridades no mundo do trabalho".

Líder dos grupos de pesquisa (CNPQ): GEPDH - Grupo de Estudos e Pesquisas em Direitos Humanos / UFRPE e GEPM - Grupo de Estudos e Pesquisas em Metodologias de Investigação Científica / UFRPE.

\section{RAFAELA MARIA JOSÉ BERTINO}

Professora Substituta da Universidade Federal de Pernambuco e Professora na UniSãoMiguel. Mestre em Controladoria pela UFRPE e bacharel em Ciências Contábeis. Integrante do grupo de pesquisa (CNPQ): Estudos multidisciplinares em Contabilidade e Cultura. 